Historic, Archive Document

Do not assume content reflects current scientific knowledge, policies, or practices. 



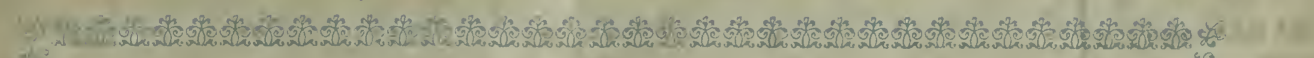

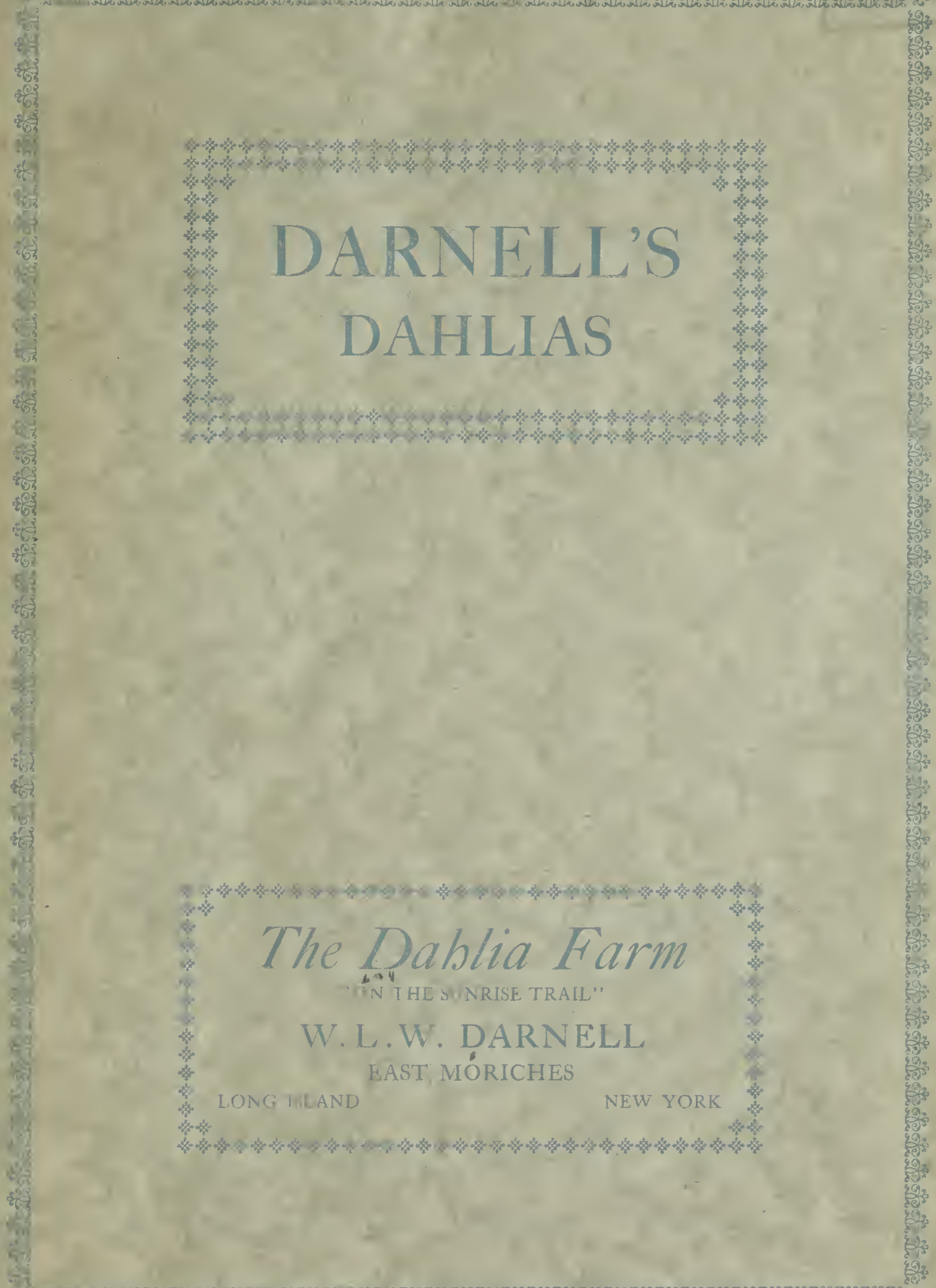

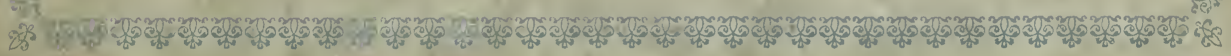





\section{To You!}

The Glory of a Garden, and the call of the Great out-of-Doors

J. A Y the coming Year bring YOU the keen delight of planning and making more charming your home surroundings, add to each day a little more work, a little more health, and the happiness that must follow. May the joy of living be enchanced by beautiful surroundings, and the Garden and growing things fill with interest every waking hour, asking only a little Knowledge, much Love, and Work: and the greatest of these is $W$ ork.

"Oh, Adam was a gardener, and the God who made him sees

That balf a proper gardener's work is done upon his knees;

So when your work is finished you can wash your bands and pray

For the glory of the garden that it may not pass away!

And the glury of the garden it shall never pass away!" 


\section{INFORMATION}

\section{PLEASE READ BEFORE ORDERING}

To those who are unacquainted with the different classes and varieties of Dahlias I would suggest that such leave the selection to me. Send me the amount of money you wish to invest and in return I will send you those that will surely delight. Also my liberal filling of the order will be more than satisfactory.

ORDER EARLY-As orders are filled in rotation-with field grown roots only-ordering early will insure the reservation of varieties that later may be sold out.

SUBSTITUTION-Orders are filled with varieties called for, and, unless substitution is asked, I never substitute.

TIME OF SHIPMENT — Unless otherwise ordered, tubers will be shipped after May 1st, by express or insured mail at my expense. Dahlias ordered shipped before April 15th will be sent only at purchaser's risk of drying out or freezing.

TERMS-Cash with order unless parties are known to me. No goods sent C. O. D. unless 50 per cent of purchase price accompanies order.

GUARANTEE - l guarantee safe arrival of all goods. I guarantee all bulbs and plants to grow and to be true to name, and will cheerfully replace any that fail in either respect. Do not plant tubers immediately on receipt of same. Put in warm, sunny position, cover lightly with damp sand, and when sprout or eye makes positive growth, plant where desired. lf, for any reason, tubers fail to grow, they can be returned at once, without labor or loss of time, with tag attached, and I will immediately send a perfect tuber to replace each one returned.

SIZE OF BULBS.-The size of the bulb or tuber does not in any way designate the size or quality of the flower. Some varieties of Dahlias always produce very small bulbs, while other varieties make large ones. Do not consider small bulbs worthless, for they are equally as good and in many cases better than large ones. Medium and small sized bulbs more often produce the finest and highest colored flowers; and in many cases the best and most effective plants. The only requisite of a Dahlia bulb is the certainty of having one or two eyes or sprouts, and whether large or small, with proper cultivation success is generally assured. A clump root, bulb, or division of a clump, pot-root, cutting, sprout, and even a Dahlia seed, will grow and blossom, all equally well. It is not the size, but the care and cultivation.

REMITTANCES should be made by bank draft, postoffice money order or registered letter. POSTOFFICE MONEY ORDERS MUST BE MADE PAYABLE AT EAST MORICHES, N. Y. Postage stamps accepted up to $\$ 2.00$. Coin should not be sent by letter unless registered

ERRORS-While my system for handling orders is as near perfect as possible, yet in the rush of business errors are possible to occur, and l wish to be promptly notified of such and will at once make same satisfactory. Keep copy of your order for comparison.

NAME AND ADDRESS-Remember to write your NAME, POSTOFFICE, COUNTY and STATE; also give STREET NUMBER or P. O. BOX as plainly as possible. 


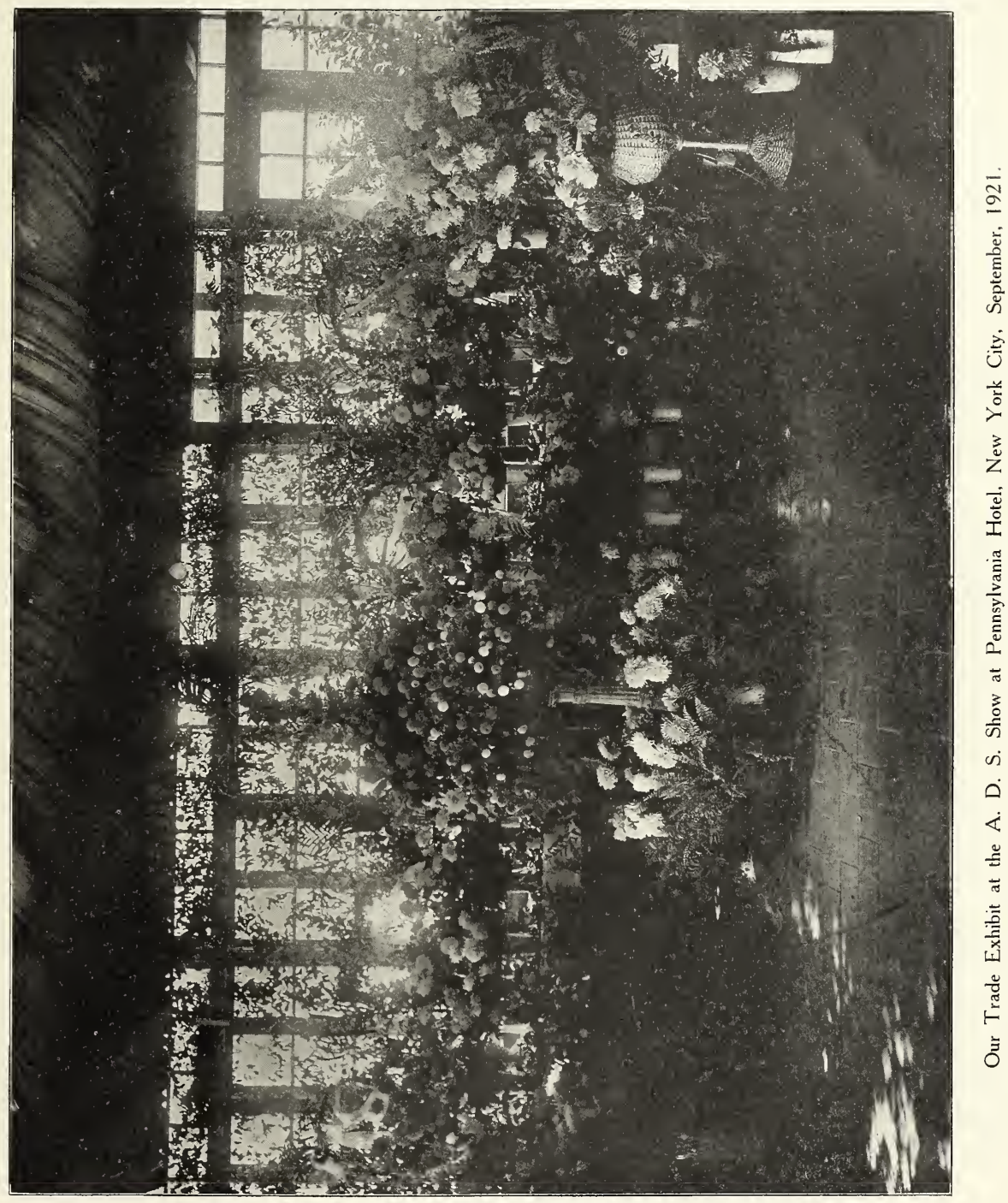




\section{How To Grow Exhibition Blooms}

Producing exhibition blooms is not a mysterious art. Late planting, severe pruning and disbudding, fertilizing and irrigating, and above all, constant cultivation, assure success where size is demanded. For such flowers the soil cannot be too rich. Spade or plough in a thick dressing of stable manure during fall, harrow, then seed to some cover crop-rye is as good as any-to keep the ground employed and assure humus for retaining of moisture and keeping soil friable during the summer heat. By the middle of May you will have a fine crop to plough or spade under, when the land may be made ready for the dahlia tubers. To guarantee the finest blooms July planting is advocated, late August is soon enough south of Philadelphia. In fact, the finest blooms 1 saw on Long lsland this past season, (and that means the finest blooms grown anywhere) came from tubers planted August 10.

When ready to plant, furrows or holes should be opened to a depth of six inches, the tuber laid on its side, sprout uppermost and the earth filled in. When the sprout is above the surface-if more than one remove all but the strongestpinch back to compel branching at ground level, guard against cutworms, and keep the ground loose with rake or cultivator. When the buds appear, remove all but the terminal bud-if that is imperfect, choose another-and cut off side shoots ful length of stem with a sharp knife, leaving the lower part of the foliage to act as lungs for the plant. To produce some of the immense fiowers seen in competition, this art of forcingis often carried to a point where the tubers have little value Too much fertilizing and watering is very injurious to the tuber crop, and forced plants produce small and imperfect flowers the following season, in fact they resemble in results over-propogated tubers. Much experiment and study has convinced me that field-grown dahlia roots keep better, and produce more and better flowers during the season following a dry year, and we always eye with suspicion any grown under irrigation. We are absolutely certain that a hard keeper like Geisha keeps best when grown in sandy soil, and rain is scarce.

\section{HARD WOODED PLANTS}

If tubers are planted early in rich soil, forcing quick growth, and the season is hot and dry, there is cause for much disappointment to the beginner. Hardened wood results, few blooms and imperfect flowers. If this is your case, be not dismayed. Cut the plant back to the ground-if the idea scares you, try two-thirds-and the new soft growth will soon burst into beauty with perfect flowers. Feed them a little, ease them of their load by disbudding, and watch the plant respond.

\section{WATERING}

We have always produced flowers of quality in quantity without any irrigation, depending on the natural moisture alone, while conserving it by constant use of cultivator or rake. But while we contend that watering is harmful to tubers, a judicious use of the hydrant is a great help in the production of large blooms. In watering, care must be tkaen that it is thorough, wetting the soil well down; and if the surface is then kept well stirred to preserve the moisture applied, one will find a soaking or two enough for the driest season. Checking evaporation at the surface checks the need of a hose.

\section{PLANTING}

THE TIME-May first to August first.

THE PLACE-ln the open air and sunshine, away from shrubs, trees, and shading places.

HOW-In hills or drills, six inches deep, three or four feet apart each way.

Too much nitrogen in soil will produce large bushy plants with a scarcity of blooms.

For large flowers feed the plant when buds develop. FERTILIZING WHEN PLANTING FEEDS THE BUSH.

When plarting, lay tubers on side with sprout pointing upward, then cover lightly with soil, and as plant develops keep drawing in the earth till ground is levelled.

\section{ST AKING}

For specimen plants staking is advocated. When planting tubers drive stake in beside tuber before covering, and when plart reaches a height of two feet, secure it to the stake, repeating operation when plants make fuller growth. This will keep the stalk from being broken by the wind and assure perfect protection.

\section{HOW TO KEEP CUT BLOOMS OF DAHLIAS}

Freshly cut flowers will keep considerably longer, and wilted flowers, if not in too serious condition, will be entirely restored in appearance, if the following suggestions are followed: Cut blossoms in early part of the day, whenever possible. Fill receptacle with water, as hot as can be borne by one's hand. Plunge the stems, but not the foliage, almost their entire length into the water; let them remain in the water until it cools, then transfer into cold water as in usual manner, with the addition of a quarter teaspoonful of salt to a quart of water. If the stems are particularly hard and wiry, water near boiling point may be used to good advantage. My suggestion would be try it and be convinced, regulating depth of water to length of stems.

\section{DIGGING FOR WINTER}

As soon as the frost cuts the tops of the dahlias, the sap recedes into the roots. Then is the best time to dig. Cut the stalks back to within three inches of the crown. In digging use a spade, and dig wide of the plant, say fifteen inches, to avoid cutting the tubers. By digging wide you take no risks. Do not pull the clumps out of the ground, but dig deep and lift the soil and tubers as you go round the plant. This enables you to get the clumps without breaking the necks. A clear, sunny day is ideal for digging dahlias, and when you have lifted the clumps allow them to stand in the sun for three hours to dry, when the tubers are ready for their permanent storing place. 


\section{STORING}

The best place to store dahlias is a good, cool cellar, such as will keep potatoes well, where the temperature remains fairly constant at forty to forty-five degrees, and the air is nei her too damp nor too dry. Cellars with heaters and cement floois are usually too dry and the roots shrivel up. This may be prevented by lining barrels or boxes with a good, heavy thickness of paper and thus excluding the drying air.

Pack the clumps one on top of the other, each clump upside down for drainage. In the stem of the dahlia is a strong, acrid juice, which if allowed to settle back into the crown may cause the clump to rot. Turring upside down allows this juice to drain out.

If temperature and moisture conditions are right, your roots will need no further attention until spring.

\section{DIVISION OF CLUMPS}

About a week before planting time bring the clumps into warmth and sunlight, cover lightly with moist earth, and when sprouts show, cut to single tubers with the portion of necks showing sprout. Never plant a whole clump; the results will spell failure. Each tuber with its neck and piece of crown containing at least one eye will give the best and strongest plant possible. The size of a tuber has very little to do with the results; small tubers are as good as large ones, and better; some of the finest varieties have very small tubers.

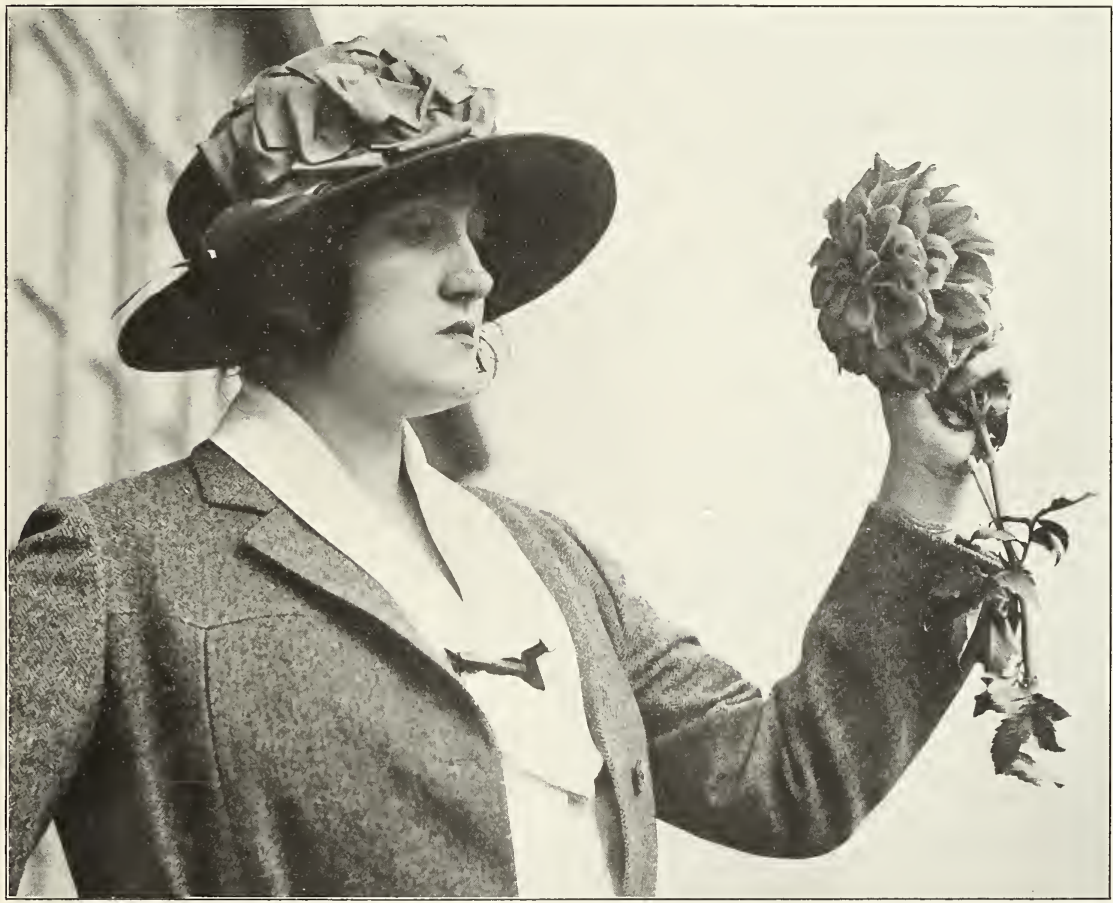

\section{BIANCA SAROLYA, PRIMA DONNA OF THE SAN CARLOS AND CHICAGO OPERA COMPANIES, WITH A SEEDLING WE HAVE NAMED FOR HER.}




\section{In Other Eyes}

"We enjoyed every moment of our Long lsland visit; glorious weather, bracing air, wonderful roads, every bit as good as our own, and hospitable welcome at each point of interest our host and guide had marked for us. The Dean, who has become thoroughly Americanized, impressively told us that we should be merciful critics, as the sand dune over which we motored had been thrown up by the sea quite recently, 50,000 years or so ago, and the dwellers thereon had been scratching for a living ever since. If so, the scratching has been to some purpose for we passed acres of glass, fields of maize"corn" the Dean scathingly corrected me-that carried me back to our trip from Batum east, and stretches of bank and water white with millions of Pekin ducks. On the return journey via the Montauk Highway we found the place where 1 made the photographs sent you. Topping the rise into the village of East Moriches we saw the swinging sign proclaiming The Dahlia Farm, and we swung into the driveway circling a bed of the most wonderful dahlias, planted among paeonies whose blooming time had passed. The small half-acre test plot on the highway gave little indication of the glory that lay beyond. The large house, surrounded with porches and solarium, hid it all from the street, and it gave me unbounded pleasure to find so much beauty tucked away in the old world quiet of this village. Two or three men were cutting and tving gladiolus for the New York market in a field nearby, and a bevy of girls from five to fifteen gave us a smiling and interested glance, otherwise our coming made never a ripple. The view was restfully ideal, and when 1 pay all my bills I intend to leave the reviewing of books to more needy plodders, and make the acquaintance of all this beauty that has use in keeping the wolf away.

The pictures can give you little idea of what 1 saw. How wo-derful they were, acres of every conceivable shade and color waving in the breeze coming up from the bay, and the blending, bizarre, barbaric if you will, resembling a gigantic Joseph's coat, made one think of some old Persian master of rug making weaving and reweaving countless designs that would end in such a masterpiece as the canopy from the bier of Shashak's Mother-in-law, that we saw in the museum at Cairo.

The most interesting part of our adventure into this fairyland, was the visit to the seedling bed. A furlong east, beside a three-acre plot planted to florists varieties, was this — seedling patch" he said-about an acre of first-mostly first-second and third year seedlings, every one, in spite of the owners depreciation of so many, a marvel of beauty. lt shocked me to learn that a very few of the feld had a future before them, the rest to be left undug and go back to the bourne of the unfit. I had the added pleasure of naming one of the beautiful things, and because I am giving your travelogue of Normandy a little more of my valuable time than I was able to afford when I "damned with faint praise" for the Chronicle, and because I had trailed you from St. Pol to that defile by the wood of Azincourt where our forefathers planted their stakes in the mud on that rainy October morning, 505 years ago, 1 named it Agincourt, even while 1 apologized to our host by telling him it was for you, and not for a headstrong king who deserved to be spanked and sent home. We saw and admired Betty Darnell, an open centered flower on a long stiff stem, named rightly for the eldest daughter of the house, and Flanders Fields, a flower worthy of honouring our glorious dead; and Heart of Darkness, can you imagine it? A wonderful name for a wonderful flower, that treated me to a dose of those thrilly shivers 1 always find in the pages of Conrad and Clifford. Then there was an immense bush of large harvest moons with a few red blotches and veins that $\mathbf{l}$ wanted called The Blood Red Dawn, but it had already been named Mona Darnell, for a sister of Betty. There was a large. peculiar purple with silver edges, and the biggest one in the field, Jean nette Selinger, that our host insisted made him dream of ice cold claret punch, and Mrs. Huber, a colour combination even you would enthuse over, and last and most astonishing of all, Priscilla Peabody, a bloom with the most wondrous colouring 1 have ever seen. l am more than ever determined to own a dahlia farm. In the three-acre field next visited the re was no attempt made to raise or use the blooms, the roots or tubers supplying the harvest. The field was planted wit $h$ the best known commercial varieties like Bianca, Attraction, Yellow King, Mrs. Ackerson, etc., in rows three feet apart, twelve inches in the row, healthy, stocky plants, unforced by fertilizer or irrigation, cultivation being done by a riding cultivator drawn by two horses, the ground being kept loose as long as it could be worked.

In the larger field behind the house the rows were further apart, and plarts three feet in the row, and there were hundreds of varieties of each of the classes. The only staking l saw was in the test lot where were gathered together the newer introductions of the many growers throughout the country, for learning their worth under the differing conditions of soil and climate.

As we climbed into the car 1 felt a keen regret take hold of me, and when we turned into the highway $I$ caught a last glimpse of that riot of colour ending on the bank of the streamlet that meandered down to the bay; and beyond the bay the dunes, a dim pearl line between the bay and the Atlantic, with one white sail close aboard, and a long trail of smoke in the offing showing some steamer eastward bound, a nd it led to my desk, and the roofs pushing into view through the dun fog beyond my window, contrastirg with the fieldsbehind me.

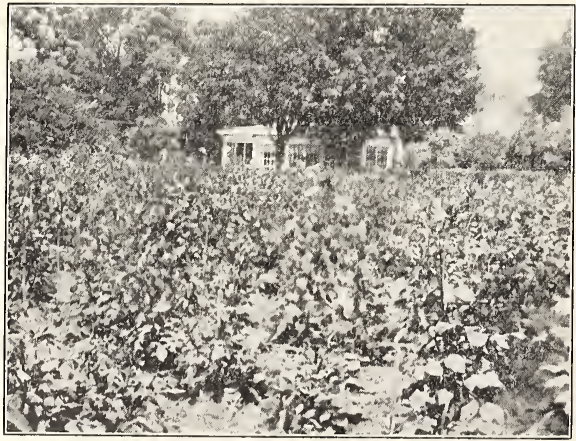

A page out of

"LETTERS FROM THE ONE TAKEN" “TO THE OTHER LEFT."

"Even Solomon in all his glory, was not arrayed like one of these."

A snapshot of test plot on Sept. 1st. 


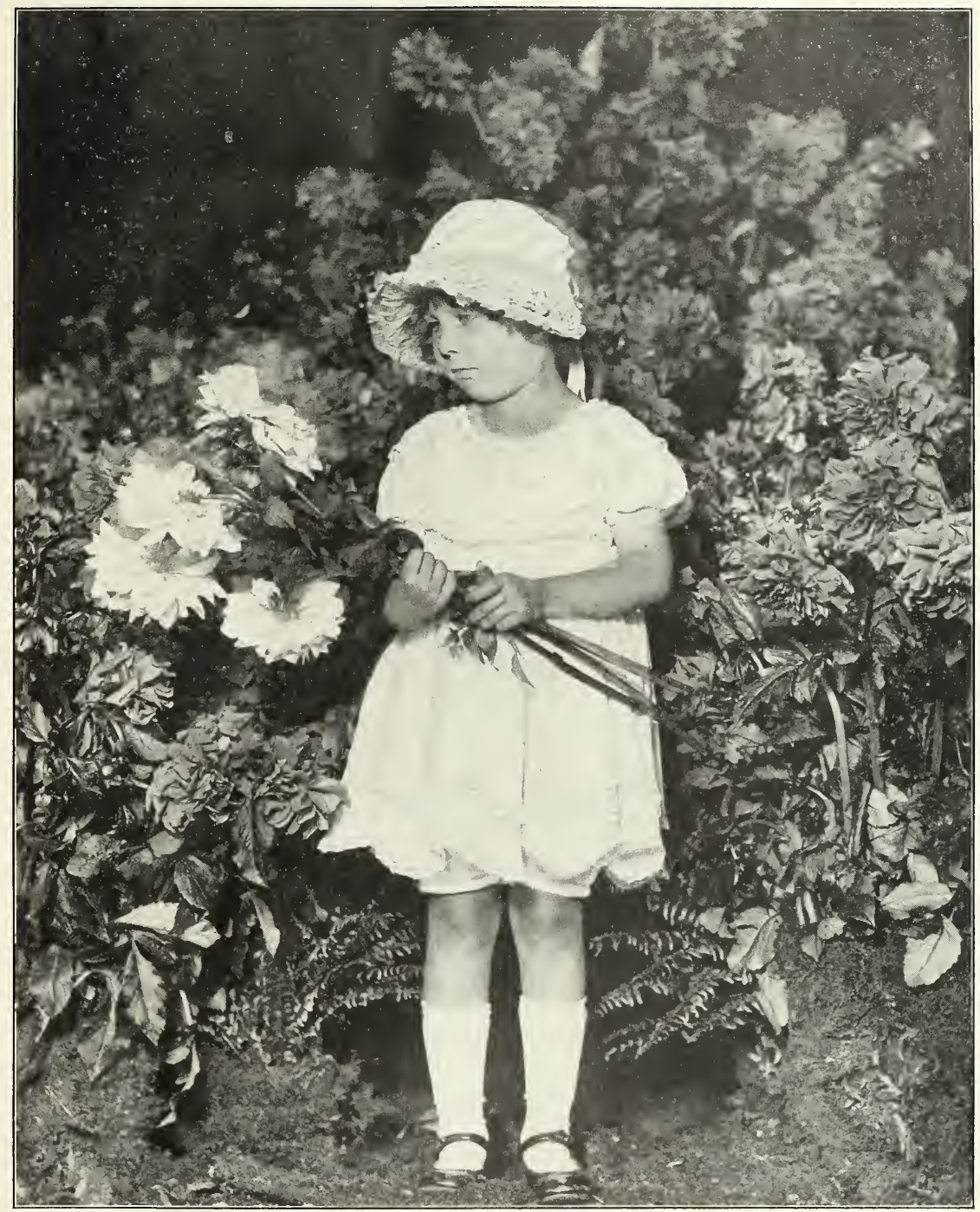

THE PREDICAMENT

Among so much beauty, who shall judge? "There is no best." 


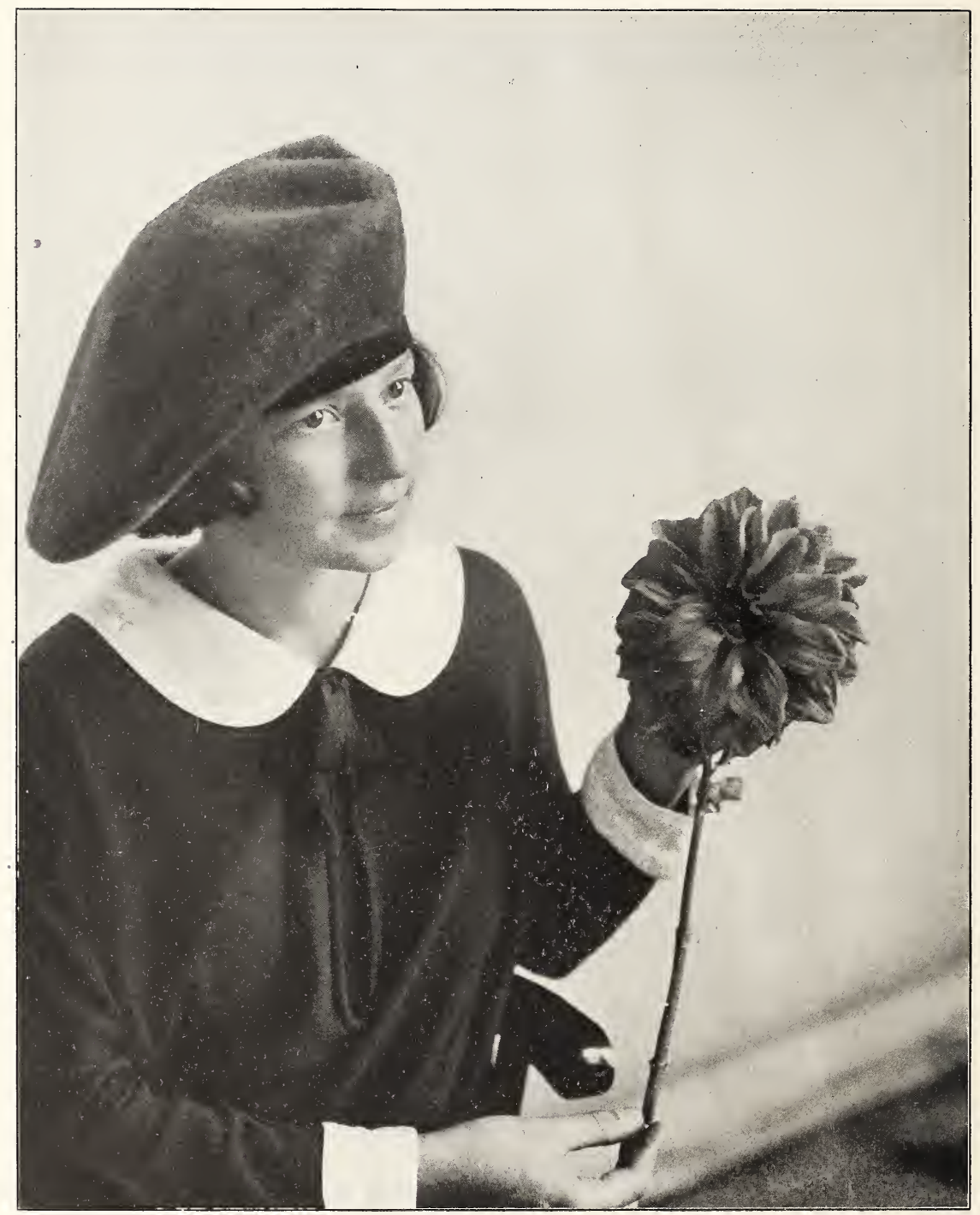

BETTY DARNELL. A fine paeony of gamboge darkening to Mars yellow at base of petals, resembling an immense tawny daisy. This beautiful flower stands well above the foliage on a long, straight stem, is unbeatable as a cut flower, and a wonderful exhibition variety.

Tubers $\$ 5.00$ Each 


\section{New Varieties For Spring of 1922}

AGINCOURT. This fine paeony-flowered dahlia is a glorified Dr. Peary, larger, darker, and of better stem, and its glossy foliage and wealth of bloom put it in the first rank for both garden and exhibition. It has the colour and the sheen of a damson, with the spectrum playing hide and seek in the heart of it.

Tubers $\$ 4.00$ Each.

FLANDERS FIELDS. An immense Hybrid Cactus seedling of Attraction and Mrs. Atherton. This flower drew the praise of every visitor, and Mrs. Vernon C. Brown honored both us and the flower with its glorious name. The suglight of victory is in the heart of each bloom, and its rays color the petals to where they are evenly edged with purple, a narrow band of mourning for those who paid the price that Victory's sun might shine on Flanders Fields.

Tubers $\$ 10.00$ Each

GLORIOUS BETTY. A decorative of burnished copper lightening to golden tan at

out disbudding, the plants a mass of bloom, and drew a pean of praise from every visitor. SOLO OUT
Tubers $\$ 10.00$ Each

HEART OF DARKNESS. A decorative of perfect habit, unbeatable stem, and large, deep blooms that are indeed the heart of dark ness. each one seemingly able to cast a shadow in the night. A friend of ours wrote: "The half dozen flowers in a hanging vase in my stateroom gleamed like jade in the starlight dusk filtering through the open skylight, and aided and abetted by the night breeze in the rigging, the murmur of the tide under our forefoot, and the gurgle of divided waters meeting again under our counter alone breaking the silence that hems me in, the darkness in the heart of those flowêr sent me to join Kurtz "deeper and deeper into the heart of darkness, and l can feel the gloom of the forests, the glitter of the reach between the murky kends, the beat of the drum, regular and muffled like the beating of a heart-the heart of a conquering darkness." That friend had borrowed us a name from Conrad, and the name fitted like a glove.

Tubers $\$ 10.00$ Each

JEANNETTE SELINGER. A large Hybrid-Decorative with the greatest depth of twist, showing the reverse like tiny new moons, or crushed fruit afloat in a bowl of Chateau Latour.

Tubers $\$ 10.00$ Each

JERSEY'S PRIDE This exceptional dahlia, originated by W. H. Waite, is a cross beLRSE S PReen King of the Autumn and George Walters, possessing the best qualities of both, and is a sturdy, fine grower, and very free bloomer. The immense flowers, in colour a beautiful blending of yellow, amber, and pink, are borne on long, straight stems well above the foliage, and it has few peers in the vase, in the garden, or in the showroom.

Tubers $\$ 10.00$. Plants $\$ 5.00$ Each

MONA DARNELL. A very large Hybrid-Cactus of a vivid chrome yellow, the base of petals suffused bright red. This fine variety has a perfect stem, and looks one squarely in the face. A grand exhibition, garden, and cutting variety

MRS. HUBER. A decorative dahlia that was quite an attraction at the exhibition of the A. D. S. at the Pennsylvania Hotel, New York, as well as in the garden. It is the most alluring flower of our whole list. While not large, its average diameter being about five inches it is a splendid cut flower, at its best under artificial light, lasts a long time after cutting, and has a color combination no other flower can equal, being a bright lemon yellow evenly tipped pure white.

Tubers $\$ 5.00$ Each 


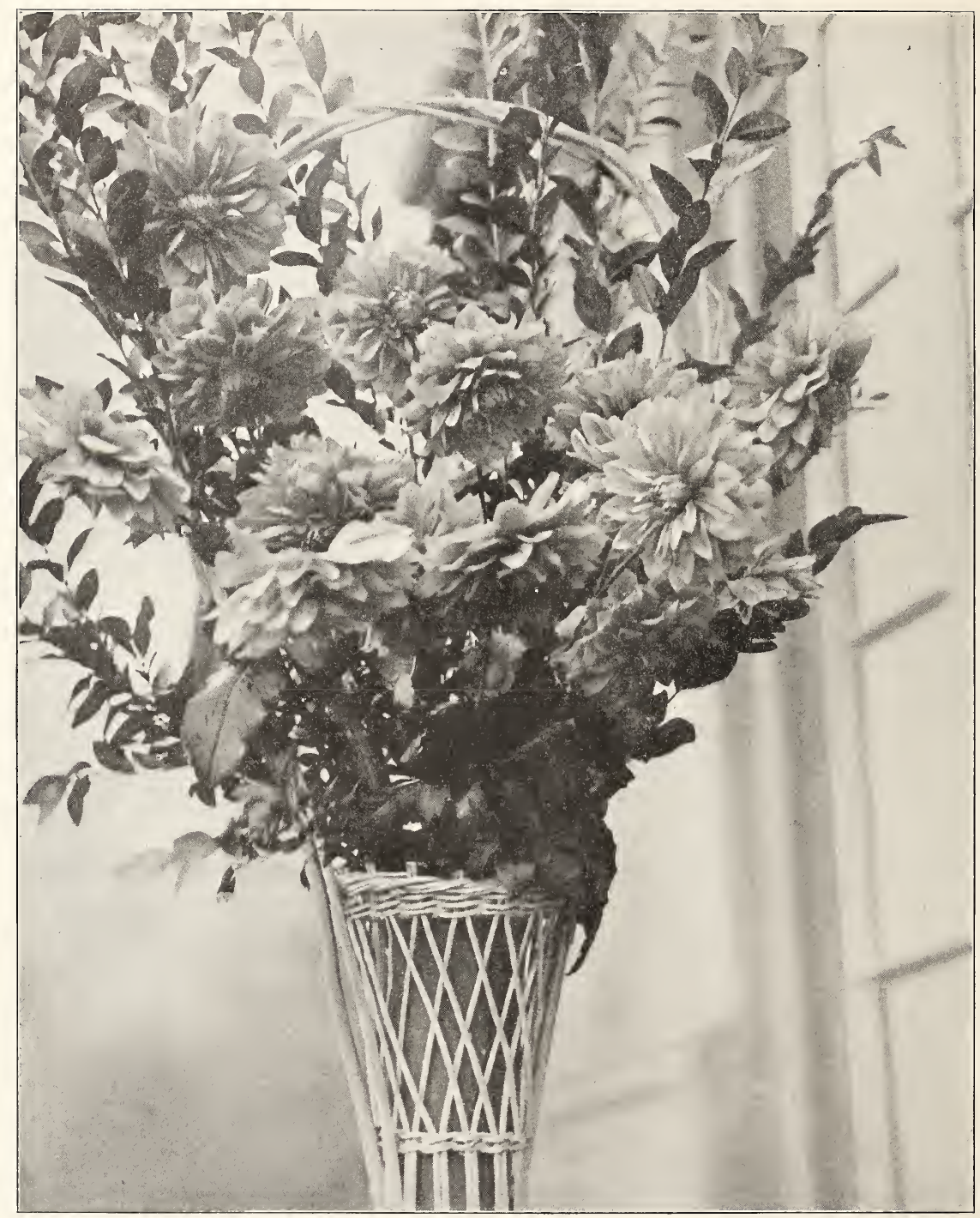

DR. TEVIS This magnificent Novelty has been a famous prize-winner ever since a seedling. In color, a beautiful shade of soft salmon rose, suffused with old gold shading to a golden apricot center. One of the largest grown; the immense flowers being held erect on fine, long, vigorous stems. At all the Dahlia shows it is a center of attraction, no exhibit being without one or more of these sensational blooms. Field Grown Tubers $\$ 1.00$ each 


\section{PRISCILLA PEABODY}

This unique decorative dahlia has been the cynosure of every eye in our gardens this past season. A medium sized flower about five inches in diameter, it is a dark reddish maroon, edged a golden tan with a bronze reverse, that, filling the centre, resembles a gold nugget nestling in a fold of velvet. Fine healthy foliage of holly green, height three and a half feet, its aura of blooms is an appeal that would make a dahlia lover of a wholesale florist.

Tubers $\$ 20.00$ each

\section{COLLARETTE DAHLIAS}

A beautiful type of flower introduced by French specialists. The flowers are single, with one or more minor petals, usually of a different color, growing from the heart of larger florets, making a collar for the disk. Great favorites in European gardens and exhibitions, they undoubtedly will become better known, than more extensively grown in America,

Abbe Hugonard, purple, petals edged white and white

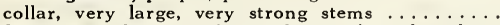
Achievement, largest of its class. A rich velvety

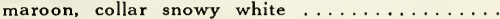

Ami Cachet, brilliant orange with yellow collar.....

Cocarde Espagnole, both petals and collar are a combination of red and gold. Flowers are very large

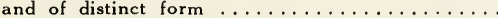

Cream Cup, large creamy white, slightly cup-shaped.

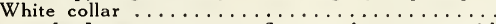

Geant de Lyon, enormous flower of maroon with white collar. Every visitor hovered over this magnificent flower a long time and it drew unending

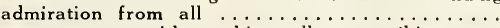

Hornet, maroon with a white collar, a striking com-

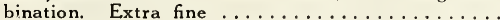

Leah, an extra large flower held erect on very stout stems. Deep crimson maroon, while the collar is white and maroon. Some flowers are heavily penciled lilac. One of the most lasting when cut.... 1.00
Merry Maid, pure carmine rose with a clear white collar. Large, perfect form, and very free flowering on fine wiry stems. A most attractive new vari-

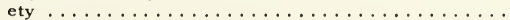

Mme. Locher, a collossus of rich terra-cotta, with a solash of orange running the length of the petal. Collar bright amber. A marvel ............

Mad. Schwarzatal, an immense flower, gorgeous purple, each petal tipped white, and a white collar..

Maurice Rivoire, red with white collar .........

Pierson Durbrow, a mammoth flower of a magnificent shade of mahogany red with the finest filled out collar of ivory yellow. A sure winner ...........

Souv. Bel Accueil, orange-red with a yellow collar. One of the largest and most beautiful. A fine flower ....................... 50

Vestal, the best pure white collarette. A gem .... 1.00

\section{CACTUS DAHLIAS}

This type of dahlia came about through the efforts of European-especially English-gardeners to produce a more loose artistic flower, to spur the waning interest of a public "fed up" on the stiff show and the small single. Previous to the introduction of the Cactus type the dahlias that grew in spite of care-rather than because of it-in our grand mothers gardens were as round, hard. stiff and ungraceful as a rreen anrls, their sole virtues being a touch of color, and unequal sturdiness. The first Cactus dahlia, named Juarez, in honor of President Juarez of Mexico, and called a cactus because of its resemblance in color to the red cactus of the plains, was found in Juxphaor, Mexico. in 1872 by I. T. Vanderberg, and sent by him to an English florist, who exhibited it in Englard in 1882. lts graceful form and brilliant color at once captured the fancy of flower lovers, and today there is no flower more popular. The proseny of Dahlia Juarezi not only "broke" irto various colors, but different shapes as well. It was by solecting the most desirable of these and reselecting the finest from each succeeding generation of plants, that the Cactus Dahlia has arrived at its present state of perfection. Today this variety is divided into two groups; the fluted ard Hybrid types, classified by the American Dahlia Society as follows:

a. True, fluted type. Flowers fully double; floral rays (petals) long. narrow, incurved or twisted, with sharp. divided, or fluted points and with revolute (rolled back) margins, forming, in the outer florets, a more or less perfect tube for more than half the length of the ray.

b. Hybrid cactus or semi-cactus type: Flowers fully double; floral rays short as compared with previous type, broad, flat, recurved or twisted, not sharply pointed except when tios are divided (staghorn), margins only slightly revolute, and tubes of outer florets, if any, less than half the length of the ray.

(Note of explanation)-All of these are to save type and useless explanations: G-stands for excellent garden use; E-for exhibition room; C-for cutting or vase use; $x x-$ very good; $x x x-$ Signifies above the average; $x x x x-$ the best of its class.

Acrobat, white, carmine edged petals, g c xxx.....

Alderman (Cactus) English variety. A genuine all around Dahlia. Clear golden orange at base, deepening at the points, with deeper reddish tint on unopened florets. Always good, on fine stem, xxx..
.25 Alight, fiery orange, e g............. .50

Arc en Ciel, aurora shaded rosy salmon, g c, xx .... .25

Bridal Robe, pure white, e g c $x_{x x} \ldots \ldots \ldots \ldots \ldots . .25$

Brisbane, a very large flower on long, stiff stems, bt orange scarlet, e $\mathrm{g}, \mathrm{xxx} \ldots \ldots \ldots \ldots \ldots \ldots \ldots .75$ 
Clara G. Stredwick, bright salmon shading to yellow, Cockatoo, yellow or white or both, odd and fine, e g c

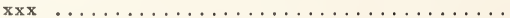

Conquest, deep crimson maroon, e g c ..........

Countess R. de Beauchamps, deep terra cotta, e g c, $\mathrm{xxx}$

Country Girl, golden yellow

.

Crepuscle, pale orange yellow, e g c, xxx ....... .25

Curlew, old rose color, massive full flowers, very long florets incurving right over center, splendid size and shape, e g, xxx

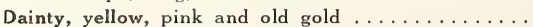

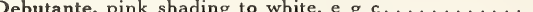

Duchess of Marlborough, delicate silvery pink. Fine for garden decoration $\mathrm{g}, \mathrm{xx} \ldots \ldots \ldots \ldots \ldots \ldots$

Edith Reynolds, cerise and amber, e g c, $x x x x \ldots . . .50$

Effective, deep amber, $g \mathrm{c}, \mathrm{xxx} \ldots \ldots \ldots \ldots \ldots \ldots . .25$

Ella Gumbert, mauve pink, g c ........... 25

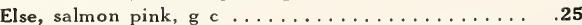

Evening Star, bright gold, terra-cotta tipped petals, e $g$ c $x \times x x$

Floradora, wine crimson, one of the best, g c ......

Florence Nightingale, not only a free bloomer, but its blossoms are of large size; good habit, brilliant scarlet, g c, xxx

Foxhunter, bright scarlet, g

Frances $W$ hite, narrow white florets, curling and twisting cork-screw fashion, freely produced from early to late autumn, e $g, x x x$

Fred'k Wenham, one of the largest cactus yet raised, color warm fawn-pink with soft salmon at the center, e g, xxx

F. W. Fellows, this variety produces large blooms with narrow florets, flower stems wiry, color bright orange scarlet, very free, e g $c, \mathbf{x x x x} \ldots \ldots \ldots \ldots$.

Genesta, amber to golden yellow, $g$

Golden Gate, a rich chrome, heavy petalage, large flower borne on very rigid and stiff stem, g c ......

Gold Queen, golden yellow, g ............................ Golden Wave, a rich, deep yellow, a magnificent varion long strong stems and always perfect to the center, g c, xxx

Goliath, yellow tipped shaded salmon, $x x x$

Golden Plover, a very fine English variety, yellow, xxx

Golden Rain, clear yellow shading to primrose at tips, $\mathrm{xxxx}$

Grandee, amber shaded pink, e $g \mathrm{c}, \mathrm{xxx} \ldots \ldots \ldots$.

Gwendolyn Tucker, pale flesh pink, e g c, $x x x \ldots \ldots$.

Hamburger, golden orange, e g c

Helene (straight), the color is an exceedingly beautiful lavender-pink, gradually changing to white at the center; free-flowering, $g$

H. H. Thomas (ir curved), few varieties combine so many good qualities. The flowers are of beautiful formation, having long, incurving florets or petals. The habit of the plant is excellent; a free-flowering variety, possessing long, straight stems and producing its flowers well above the foliage. The color is a beautiful rich deep crimson, e $\mathrm{g} c, \mathbf{x x x} \ldots \ldots \ldots$

Hugh McNiel (English Cactus), stems long and stout; tree flowering and always full to center. Color beautiful shades of dark pink, e $g c, x x \ldots \ldots$.

Irresistable, an enormous flower with long incurving petals, color yellow suffused with rose, a band of rose color running up each side of petals, e, $\mathrm{xxx}$...

J. H. Jackson (Straight), the finest black Cactus Dahlia in existence. An exceptionally satisfactory all-round Dahlia; one of the most prominent for garden decoration, superb as a cut-flower variety ard equally good as an exhibition flower. Color, a perfectly gorgeous, deep velvety, blackish-maroon. Gigantic in size. Every Dahlia lover should grow this variety, $\mathrm{g} \mathrm{c}, \mathrm{xx}$

Johannesburgh, golden amber, e ..........

John Burns, bright crimson, e $\mathrm{g} c$, $\mathrm{xxx} \ldots \ldots \ldots \ldots$

John Peel, intense rich crimson without shading, florets beautifully formed and nicely incurved, flowers

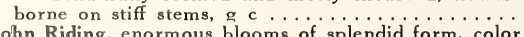

John Riding, enormous blooms of splendid form, colo rich deep crimson, $\mathrm{x} \times \mathrm{xx}$.
Kalif, a robust grower, bearing its flowers in profusion on long rigid stems, an extra large flower of a rich

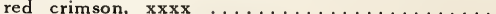

Lady Fox, deep rich scarlet, g $c \ldots \ldots \ldots \ldots \ldots$

Lawine, pure white, $g \mathrm{c}, \mathbf{x x x} \ldots \ldots \ldots \ldots \ldots \ldots$

Marathon, a beautiful deep, rich purple. Large flow$\mathrm{er}$, and one of the best of its color, g c, $\mathrm{xxx} \ldots . .$. .

Marjorie Caselton, rose pink petals tipped white, g . . .

Marjorie Seale, buttercup yellow, e c .........

Marguerite Bouchon, deep pink, e, xxx ........

Mauve Queen, a beautiful clear mauve, e $g$.......

Melody (English Cactus), one of the most distinct, color being clear yellow for half the length of florets balance pure white, stems good, $x x x$ f flor

Minnie Baxter, deep maroon, $g \mathrm{c}, \mathbf{x x x} \ldots \ldots \ldots \ldots$.

Miss Lena Ashwell, tomato red, e, $\mathrm{xxx} \ldots \ldots \ldots \ldots$

Miss Stredwick, soft yellow at base, quickly changing to a lovely tint of deep pink, a magnificent

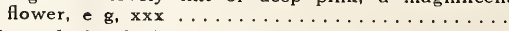

Monarch, bright bronzy red, e ............

Mr. Geo. Caselton, dark maroon, shaded purple, c .

Mrs. Caselton, rosy salmon, white tipped, g .......

Mrs. Charles Scott, old gold, g . . . . . . . . .

Mrs. Douglas Fleming, the finest white cactus yet raised, the florets are narrow and so numerous that they make a most massive flower, $x x x$.......

Mrs. E. S. Brown, a grand variety for garden or cutting, intense crimson, e $g$ c $\ldots \ldots \ldots \ldots \ldots$.

Mrs. H. J. Jones, scarlet, tipped white, g c, xxx ...

Mrs. J. Emberson, fancy, lemon yellow, slashed pink, g

Mrs. Reginald Bailey, purplish crimson, e g c, xxx....

Mrs. Reginald Gurney, amber and rose, e c ....... Mrs. Seale, fancy, rich color of crimson, tips pink, c. .

Mrs. T. G. Baker, rich orange, e g c .......... boldly tipped is deep amber, but makes it not only unique but very striking, the flowers are large and if disbudded huge, e $g, x \times x x \ldots \ldots \ldots \ldots \ldots .1 .00$

Pink Pearl, beautiful flesh pink, $c \ldots \ldots \ldots \ldots \ldots .25$

Prima Donna, ivory white, tinted with violet, e, $\mathrm{xxxx} \quad \mathbf{5 0}$

Rackete, bright scarlet, g c ............25

Reine Amelia, bright rose, g c ........... 25

Rev. D. R. Williamson, deep velvet crimson, $g$ c ... $\quad .25$

Rev. T. W. Jamieson, yellow and lilac rose, e c, $x \times x \quad .25$

Rhein Konig, snow white, $x \mathbf{x x} \ldots \ldots \ldots \ldots \ldots \ldots . .50$

Rosa Siegerine, apple blossom pink, e g c, xx .... $\quad .50$

Soleil Couchant, a glorious bright salmon shaded orange scarlet, fine exhibition variety, $\mathrm{xxx} \ldots \ldots$

Sybel Green, ivory white, g c ................... Sweetbrier, a superb garden cactus of an exquisite shade of pink, a mass of flowers on strongs stems, e

Tinted Queen, light shade of yellow, tipped with pink Thomas Challis, a very rich tone of salmon-red or rosy-salmon. The florets are beautifully incurved and arranged with the utmost regularity. This variety can be recommended as one of the best for cut-flower purposes, $\mathrm{xxx} \ldots \ldots \ldots \ldots \ldots \ldots \ldots$

Triumphator, melon or cream yellow, $\mathrm{xxx} \ldots \ldots \ldots$ Tustu (Straight), one of the most beautiful to date. The color is perfectly gorgeous-a beautiful velvety maroon. The petals are very long, tightly quilled and arranged in exact regularity, completing an acquisition which we can highly recommend, g c ...

Uplands, bright crimson, scarlet, e $\mathrm{g} \mathrm{c}, \mathrm{xx} \ldots \ldots \ldots$. Valiant, a giant flower of brilliant crimson, carried on a giant stem. Perfectly incurved, florets long, narrow and intermingled, $\mathrm{e} g \mathrm{c}, \mathbf{x x x x} \ldots \ldots \ldots \ldots \mathbf{1 . 0 0}$

Vesuve, rich geranium lake, $c \ldots \ldots \ldots \ldots \ldots \ldots \ldots .25$

Veteran, of good habit, and well formed flowers on splendid stems. Color crimson scarlet, g c ......

Vicar of Wasperton, base of petals a beautiful pink with an overlay of yellow, edging off to a delicate cameo pink. The center of the flower is a charming primrose yellow. This new creation is one of the best of the English importations, having gigantic size and being ideal for exhibition purposes. The florets are very long, tightly quilled and beautifully incurved, $e \mathrm{~g}, \mathrm{xxxx} \ldots \ldots \ldots \ldots \ldots \ldots 2.00$

Vulcan, a remarkably full and large English flower. Color deep maroon, good stem, e g, $x \times x \ldots . \ldots 1.00$ 


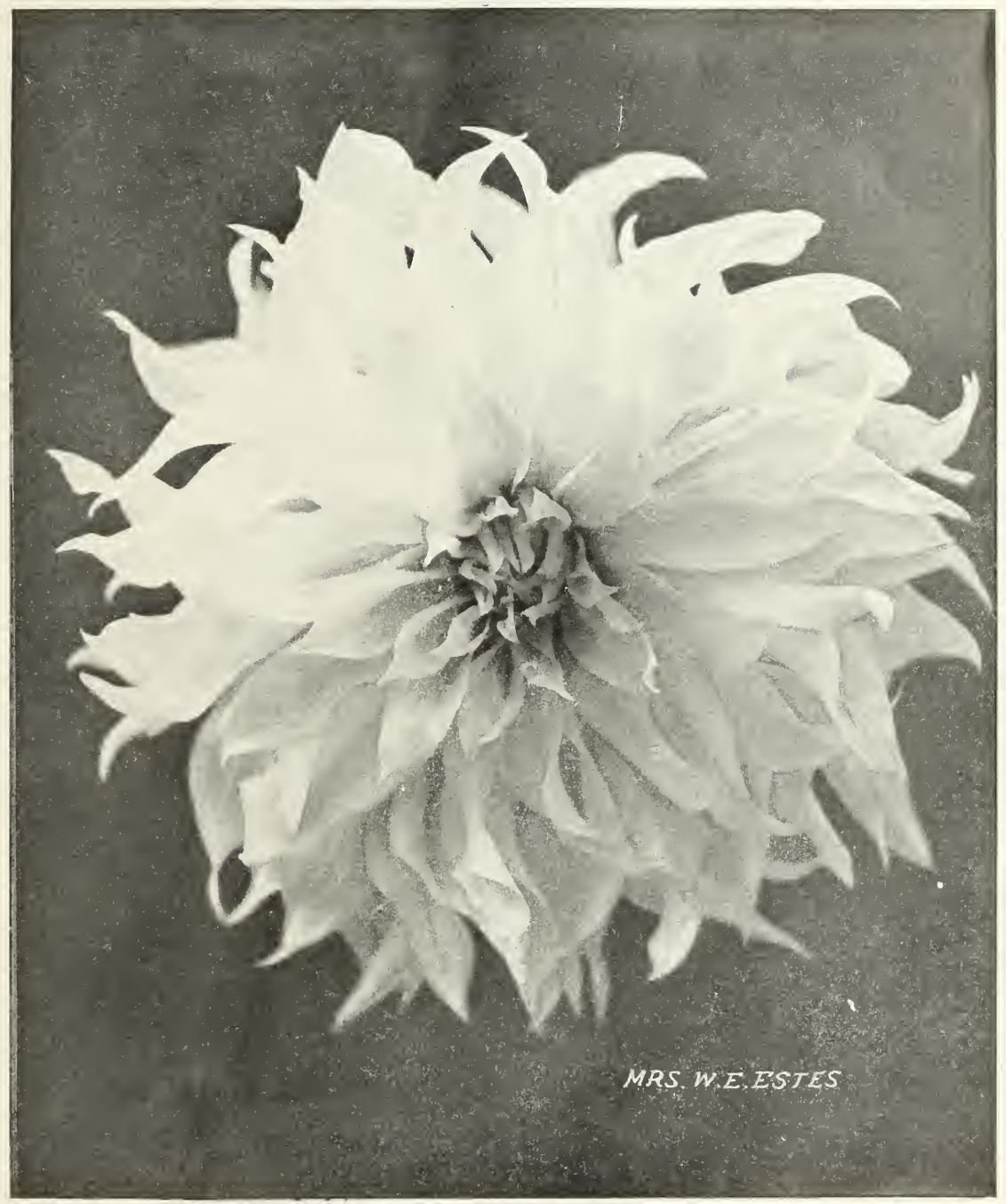

MRS. W. E. ESTES Hybrid Cactus. This is a fine snow white Dahlia. The imm ense bloom, with its petals deep and full, is held high above the foliage on a long, strong stem, making a most excellent cut flower. For garden effects white flowers are essential to bring out the other colors. We have been rnore than gratified by the many glowing descriptions and the enthusiasm of our customers over this wonderful Dahlia. When grown en masse, the flowers are like "waving ostrich plumes." Field Grown Tubers $\$ 2.00$ each 


\section{HYBRID CACTUS}

Amber Glow, bright yellow, deepening to orange at center. Unbeatable for exhibition .......... $\mathbf{3 . 0 0}$

Amphion, this rare beauty of soft mauve has fluffy curled and twisted petals; stems long. A charming trower ................. 1.00

Attraction, large, elegant, full flower, of a clear, lilacrose. The habit is perfect, with long strong stems holding the bloom stiff and upright. A very attractive variety $\ldots \ldots \ldots \ldots \ldots \ldots \ldots \ldots \ldots \ldots \ldots$.

Avalanche, a gorgeous, glistening, fure white, of the same tyfe as Kalif. The flowers are large size, and are produced on long, stiff stems, well above the

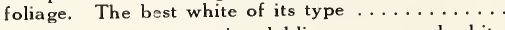

Ballet Girl, a very attractive dahlia, orange and white. Very free blooming, flowers large .............

Bianca, coloring is beautiful rose-lilac with white shadings, and blooms is held perfectly erect on strong, stiff stems. Free-flowering . . . . . . .

California Enchantress, a monster bloom of great sub stance and a delightful shade of pale pink. Hybrid Cactus are greatly in demand because of their size and erect stems. This has both these admirable qualities, combined with freedom in flowering. Strong tubers ........... massive cactus dahlia of the Colossal Peace, a massive cactus dahlia of the acros; later in the season when the flower show a centre it is a wonderful paeony dahlia; color creamy white at centre, shading violet rose with lighter tips, early and profuse $\ldots \ldots \ldots \ldots \ldots$

Diana, rich crimson, shaded violet. A giant; broad,

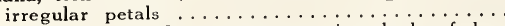

Dorothy Durnbaugh, a most attractive shade of deep rich pink, flowers are immense in size; of fine form ard habit, with strong stems, that hold up well; one of the best Cactus Dahlias in cultivation, fine for

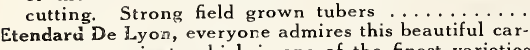
nure rose giant, which is one of the finest varieties for garden decoration. Hybrid Cactus type that is distinct in shape from all others, the petals being broad, curled ard wavy, forming a fower more than six inches in diameter and four inches deep, but without stiffness or formality. Color a rich Royal purple with a brilliant suffusion difficult to describe

Garibaldi, one of the best from Holland. A very full and very large flower with very fluffy petals on a good stem. Color is a bright scarlet. Particularly

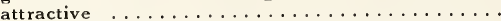

George Walters, this is the most wonderful Dahlia ever offered. It is a Hybrid Cactus of exquisite coloring, being a bright salmon-pink, artistically suffused with old gold

General Joffre, deep rich crimson, edged scarlet. A wealth of large blooms on long strong stems, petals that twist and whorl make this a great attraction.

Golden West, another California production that is one of the very best of its type, and has been the leader for florists' use in this locality for three years. Its keeping qualities are of the best. Has extra long stems that are graceful and wiry. A very large flower, often five inches across, of a striking old gold color, which makes this one of the most sought after

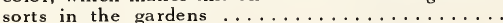

Great Britair, a large lilac mauve, good stems.....

Helen Durnbaugh, delicate blush, deepening rapidly toward the center to an intense, soft glowing pink that defies description; blooms medium to large,

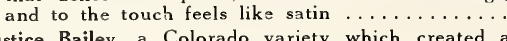

Justice Bailey, a Colorado variety which created a sensation in 1916. Color rich glowing pink, shading a little lighter toward center. Large flowers on good stems

Kalif, a monster Cactus of perfect form. Color is rich, pure scarlet. The large flowers are borne on long, stiff stems and are held erect. A most satisfactory variety. $5 \mathrm{ft}$.

La Favorita, a splendid novelty, shading from a dark reddish salmon in the center to salmon-pink at the twisted points. Perfect form; strong long stem; fine cut-flower ....................
Lady Helen, a very beautiful flower, popular every where; in color a mixture of carmine rose and cream with cream tips ................. 3.00

Magnificent, a magnificent California Dahlia that is more than the name implies. Beautiful incurved, long petals of a blending of apricot, copper and orange that cannot be described, making a truly magnificent flower of immense size on long straight stems. Fine habit and a very profuse bloomer throughout the ssason $\ldots \ldots \ldots \ldots \ldots \ldots \ldots \ldots \ldots$

Mrs. Edna Spencer, a new introduction. A flower of a delicate and equisite shade of orchid pink. Very beautiful and of good formation and stems. Received Certificate of Merit at the Trial Gardens, San Rafael, California, 1917. A lasting cut-flower of unusual color. This is one of the finest of Mrs. Edna Spercer's productions ............ 1.50

Mrs. R. Lohrman. A pure golden yellow with a full center and immense size. A fine keeper. Its broad slightly twisted petals make this a very unusual form and a beauty for exhibition as well as cut. A Cali-

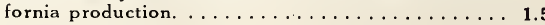

Mrs. T. A. Munro, a Dahlia with blooms over six inches that are a beautiful amber color shading to old gold. lt has a perfect stem that most cactus Dahlias lack, holding same well above the foliage.. 1.0

Mrs. Warner, white shaded blush, petals irregular, wavy ard slightly incurved, ideal, stiff stems, perfect habit ..................... 1.00

Nibelungerhort, large, broad petalled, more or less twisted, a beautiful shade of old rose, tinged golden apricot. Very free ................

Red Cross, one of the very best Danlias in existence, a beautiful combination of red and yellow. It is a very strong grower, and the flowers are produced freely on long, strong stems ........... 2.50

Rheims, delicate salmon pink shading to orange, with lighter tips. A glorious garden or exhibition variety 1.00

Ruth C. Gleadell, a soft yellow, shading to an apricot bronze on the outer petals. The immense flower is held erect on a strong stem far above the foliage $\mathbf{1 . 5 0}$

Ruth Van Fleet, clear light canary yellow. This is without doubt the finest yellow Cactus Dahlia ever introduced. The stems are extra long, often measuring 16 inches. The flowers are extremely large, measuring from 6 to $81 / 2$ inches in diameter and are held perfectly erect on its stiff, long stems. It should be seen to be appreciated .......... 2.00

The Grizzly, one of the very best novelties. A great dark velvety maroon beauty. This is a wonderful prize winning dahlia. Flowers of immense size are held high above the fine foliage on extra strong, long stems, makin $\simeq$ a fine showing ..........

Tom Lundy, an introduction from California and one of the largest Hybrid Cactus Dahlias grown. Of a dark velvety red, the blooms are held on long, stiff stems. A sensational novelty ......... 1.0

Walkure, sulphur, deepening to gold in centre. A giant, erect on long stem .............. 1.00

Wodan, a hybrid of rare beauty and form. Large broad flowers frequently measuring eight inches. The graceful arrangement of its semi-incurved tubular petals of a pleasing, delicate, salmon rose color, blending to old gold at center completes this model of perfection. Of fine habit and good long stems..

Yellow King, too much cannot be said for this wonderful hybrid Cactus. Every visitor thought it a giant chrysanthemum. It is a pleasing shade of yellow, standing straight on a wonderful stem, and for cutting it has few peers $\ldots \ldots \ldots \ldots \ldots \ldots$ 


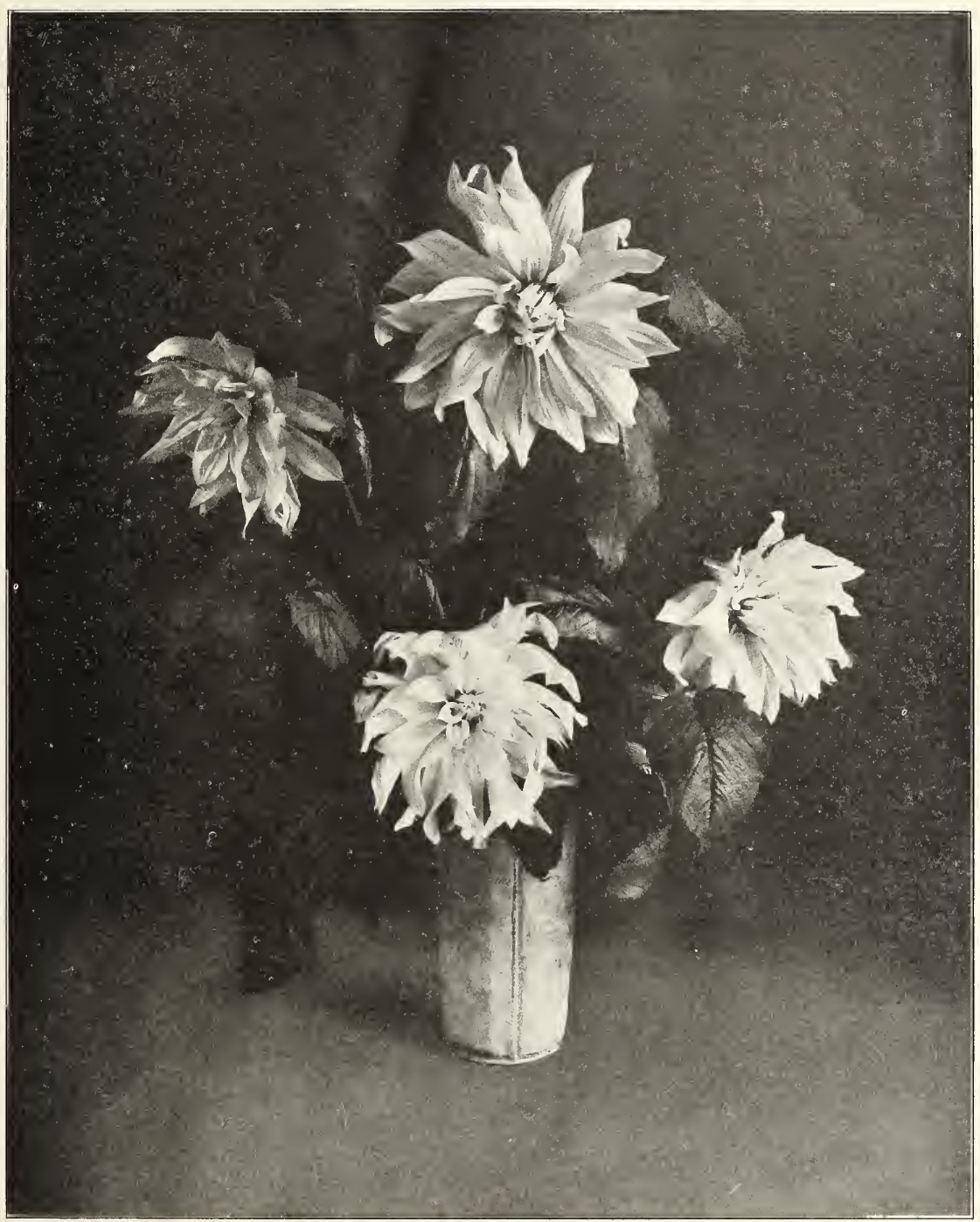

GLADYS SHERWOOD A giant white hybrid cactus of fine form, held erect on good stem. The flowers are often 7 to 8 inches in diameter, and I have had blooms over 9 inches where disbudded. This is not only a fine exhibition variety, but a wonderful attraction in the garden. Field Grown Tubers $\$ 3.00$ each 


\section{DECORATIVE DAHLIAS}

The Decorative Dahlia is the pride of all Dahlias, sianding out pre-eminently. In the garden the plants are strong, sturdy, vigorous growers, with heavy, dark green foliage, and a remarkable constitution. The blossoms are produced in great profusion, which is exceptional for a type of giant-flowering Dahlias. For cut-flower purposes they are unsurpassed, having long, straight stems of wiry stiffness, and carry their flowers in a pleasing upright manner; then principally their lasting qualities when cut-they are unequaled, lasting longer than any of the other types. As an exhibition flower the Decorative Dahlia is the most gigantic of all Dahlia blossoms having beauty, substance, quality-all essential characteristics of a true "Model of Perfection." As a decorative flowers they are frrst in every respect; being graceful, adapted to designs, and most artistic.

The blossoms of the Decorative Dahlias are large, flat, but beautiful in shape, and full to the center; the petals are somewhat irregularly situated, long, broad, flat and nearly straight.

Argyle, this is one of the finest decoratives yet pro duced. It has a long stiff stem and its coloring is rich apricot suffused with carmine, making a most gorgeous effect. We control the stock of this variety and unhesitatingly promise it worthy of first place in our collection, $\mathrm{x} \times \mathrm{xx}$

A. E. Johnson, pink, distinct form

Azalea, soft, creamy yellow. Unusually attractive with its many rows of long, narrow florets. Long graceful stems $\ldots \ldots \ldots \ldots \ldots \ldots \ldots \ldots \ldots \ldots \ldots$

Breezelawn, this is the most perfect of any scarlet yet grown; while of a fiery shade, yet it is soft and clear and is very effective in massing, $\mathbf{x x x x} \ldots$.

Bonnie Brae, cream, shaded blush-pink; the flowers are of true decorative form and immense in size, but not suitable for cutting, as the enormous flowers are apt to be too heavy for the stem ...........

Berch van Heemstede, primrose yellow, with rich golden sheen. Fine for cutting

Byron Streeter, indescribably fascinating shade of lilac purple overlaid with bluish sheen. lmmense flower

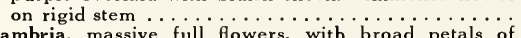

Cambria, massive full flowers, with broad petals of rich rose pink, toning to white in center. Long, rigid stems $\ldots \ldots \ldots \ldots \ldots$ distinctly penciled with bright armencita, clear yellow, distinctly penciled with bright
scarlet. Very beautifully formed flower of immense size. Fine stems and a good keeper; compact

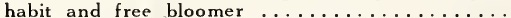

Carolyn Wintjen, a very beautiful salmon pink with rose shadings. Large flower with a good stem. A vase of these lovely pink blossoms received First Prize at the California State Floral Society's 1920 Exhibition $\ldots \ldots \ldots \ldots \ldots \ldots$ one of the best Delice, the richest shade of pink. One of the best
varieties known for keeping. Extensively used by

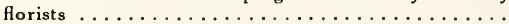

Dorothy Flint, a blending of salmon and pink with a yellow stripe running through the center of the petals. The flowers are from 6 to 7 inches in diameter and are borne on long stems in great abundance, making it valuable for cutting. It is worthy of a place in the most exclusive gardens. 2.00

Dream, a peculiar peach pink shade with an amberlike glow. Of great beauty and perfect form, standing erect on long, strong stems high above the foliage. New Holland sort that is ideal for cutting 1.00

Eagle Rock, large, massive flowers of creamy white, blended with an apple-blossom pink; quite distinct. Healthy grower and good bloomer; stout stems...

Edith Wooster, one of the finest garden varieties produced in recent years. The color is a blending of golden yellow and sunset red which cannot be accurately described, but suggests the tea rose combination. The plant has an upright habit with the flowers on long erect stems $\ldots \ldots \ldots \ldots \ldots \ldots$

Earle Williams, this is a giant flowering Dahlia, we having grown it as large as 10 inches in diameter. The colors of brilliant crimson and white are well distributed. Plants are very free in bloom. This is one of the finest and most attractive Dahlias ever introduced

Futurity, large blossom, of old rose. Beautifully formed. Stem is long, standing well above the foliage. Splendid cut-flower, always in demand

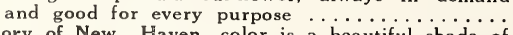

Glory of New Haven, color is a beautiful shade of pinkish mauve. Plants are tall, robust growers, and produce large blooms with remarkable freedom on long, strong stems. Will be indispensable for exhibition
Hochsai, yellow overlaid with deep red; large flower

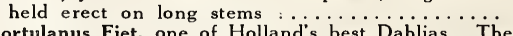
Hortulanus Fiet, one of Holland's best Dahlias. Th coloring of this variety is wonderful-a beautiful shade of salmon exquisitely blending to yellow

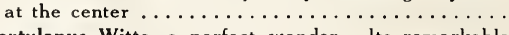

Hortulanus Witte, a perfect wonder. lts remarkable qualities are excellent type, perfect form, and purity of color. The flowers are borne in a miraculous profusion upon long, stiff stems, well above the foliage. The color is a waxy, almost glistening pure white; a beauty in every sense of the word......

Insulinde, colossal flowers of a rich golden orange color. Form of flower everything that could be desired. Admirable for cutting and exhibition. One

of the most artistic yet produced ........... 3.0

Jane Selby, without exception, the greatest prize-winner since its introduction in 1917. Delicate mauve pink, of immense size and true decorative formation. The large flower grows well above the foliage; wonderful stems, long and stiff; unusually fine for cutting and exhibiting . ............

Jeanne Charmet, pink, deepened at edges of petals and showing lighter shades in center of petal, very long stems, large blooms and great bloomer, fine any

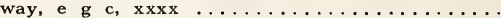

John R. Baldwin, a fine cutting variety and great

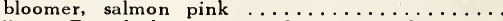

Joffre, a French decorative of fine form and exquisite beauty. Delicate pink shading to white in center. A favorite cut-flower for decorating, long stiff stems

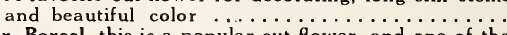

Jhr. Boreel, this is a popular cut-flower, and one of the most beautiful decoratives. The flower is of finest formation, large and deep, and of most beautiful old gold color. Stems long and strong. A great

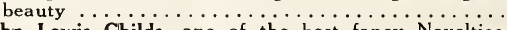
Novelties. Yellow, suffused, splashed and striped with brilliant scarlet, and generally tipped white. Bi-colored dahlias occasionally have a flower of solid color. In this case the red blossom is often tipped white $\mathbf{4 . 0 0}$

Judge Marean, a well known exhibition variety; it is a beautiful combination of colors, almost indescribable. A fire grower and a free bloomer. Plants $\$ 3.00$, tubers $\ldots \ldots \ldots \ldots \ldots \ldots \ldots \ldots$ Dahlia is well King of the Autumn, this beautiful Dahlia is well ers. Demand far exceeds the supply always. It has every good feature. Fine coloring, fine stem, fine form, good size, and excellent keeping qualities 1.00

Le Grand Manitou, enormous bloom, white striped and blotched with deep purple ............

Lucero, bronze buf, shaded brighter, e g c, xxxx.

Mabel B. Taft, 1920 introduction. Winner of the 1919 Gold Medal for the best 50 blooms of one variety. A beautiful decorative of apricot shading to yellow. Fine stems and a good flower for all

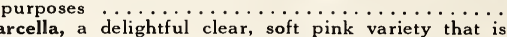

Marcella, a delightful clear, soft pink variety that is bound to become a great favorite with everyone,
especially Florists. A wonderfully free bloomer on long stems, that hold the blooms rigidly erect. Very perfectly formed and is second to none in keeping

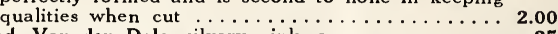

Mad. Van den Dale, silvery pink, e $\mathrm{g}$ c, $\mathrm{xxx} \ldots \ldots \ldots .25$

Maiden's Blush, style of Mad. Van Dale, but larger and heavier bloom and as floriferous as Sylvia, xx, e. .

Millionaire, the color of this variety is a dainty lavender with a pink sheen overcast, and shading to white in the center. The flower is immense in size, very deep and heavy, $x x x x \ldots \ldots \ldots \ldots \ldots . \ldots \ldots$ 


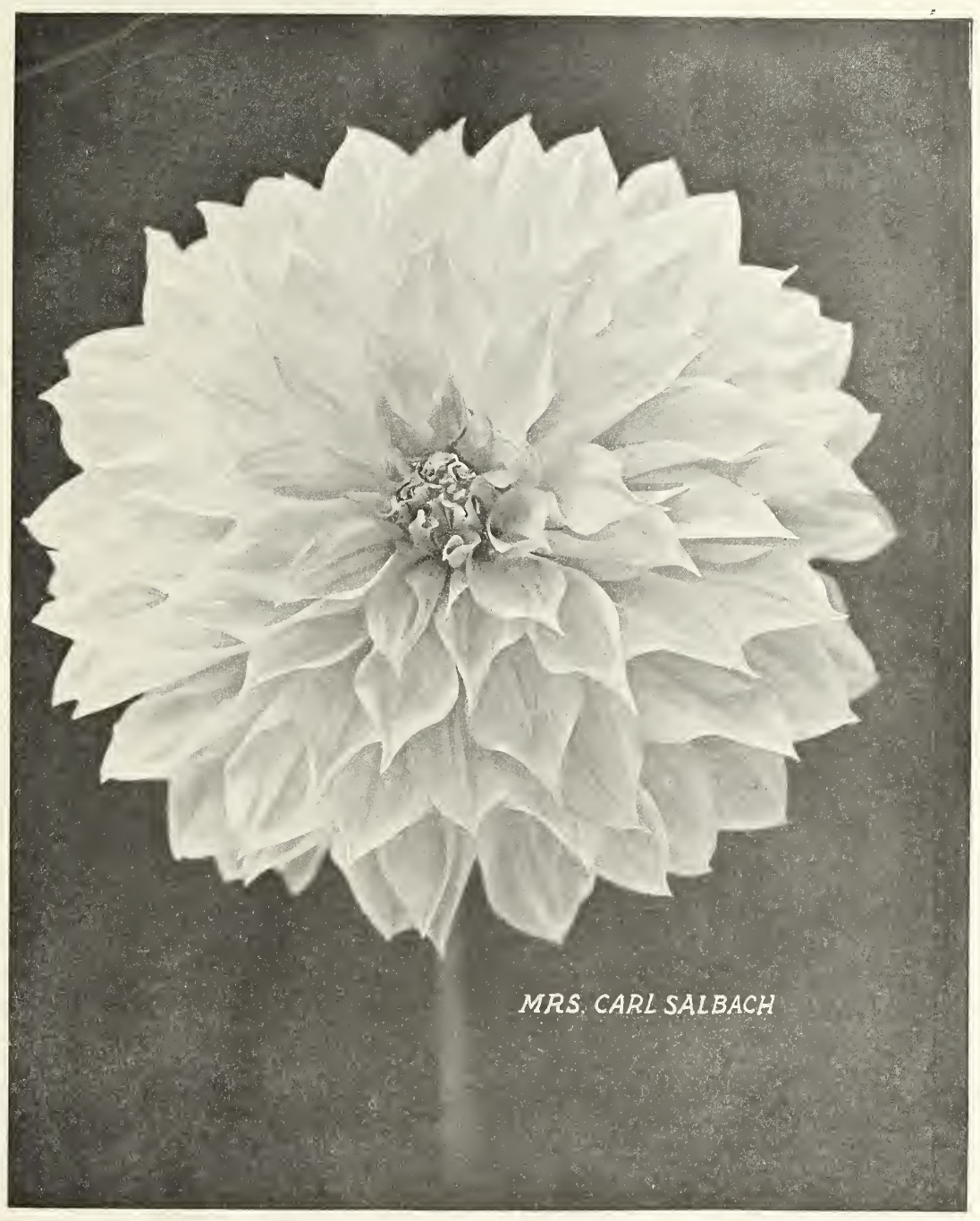

MRS. CARL SALBACH A large flower of marshmallow pink, lighter in centre, every petal outlined with a deep mauve. The stems are very long and strong, holding the blossom rigidly erect, and I believe it one of the very best cutting varieties produced in America. A consistent prize-winner since its introduction, it has proved its right to the Gold Medal won in 1919.

Field Grown Tubers $\$ 3.00$ each 
Mina Burgle (California Decorative). Rich cardinal red, a very free bloomer on very good stems. Exceptionally good as a cut-flower

Mephistopheles, this is probably the finest Dahlia of its class that has ever been introduced. The flowers which are very large and of fine form, are a vivid scarlet

Miss Leota Cota, a more beautiful blending of creamy buff and pink would be hard to imagine, the flowers are enormous, coming 10 inches in diameter. This is not good for cutting as the huge flowers are usually too heavy for the stems, but as an exhibition flower it is going to be hard to beat

Mary C. Burns, a most wonderful color of gold with the reverse of red, a very free bloomer with long stems and large flowers

Morocco, rich, deep purple, distinctly tipped white, xx

Manitou, amber bronze, distinctly shaded with pink, large

Mrs. Atherton (Howell), we introduced this glorious decorative to the I ublic, and each year since has proved all we claim for it. A robust grower with mammoth bloom on strong stem, it is peer of the best in yellows, $\mathrm{xxxx}$

Mrs. F. C. Burns, a novelty. This beautiful shell pink decorative is one of the best for all purposes and never fails to attract attention by its lovely coloring. A prize winner

Mons. Le Normand, an early and continuous bloomer. of good habit, producing its immense flowers on long stiff stems. In color a rich golden yellow, with occasional reddish markings. The largest and finest of this color. Ore of the most satisfactory garden varieties and equally good as an exhibition sort

Mrs. Frylinch, clear, deep scarlet-red, A broad, flat flower of gigantic size. Undoubtedly the largest and finest of the deep scarlet-red Decoratives. The plants are of good habit producing their flowers well above the foliage

Mrs. Wm. H. Pepin, one of the best white Decoratives in existence. It is greatly superior in both size and form to the justly celebrated "Mme. Marze," which has for several years been rgearded as the best white in this class. As an exhibition flower it is a winner every time

Mrs. J. R. Howell, (Howell) An immense lilac Decorative with beautiful shadings. Magnificent.

Mrs. R. R. Strange, a burnished copper with faint shadings of old rose and old gold. Not only a splendid garden flower with its fine large blooms held high above the foliage, but also very useful as a cut-flower, having a new Autumn coloring so much in vogue

Mrs. T. B. Ackerson, our best cut flower. Brigh carmine, tipped and shaded with whitish pearl when fully open reflecting the sun's glory. Of good size and long stem

Mrs. Warner's Favorite, everyone who has seen it growing prorounced it the acme of perfection. In color it is a deep mauve pink. some might describe it as a cattleya color. Solendid for exhibition and for the garden. Plants (only) ..............

M. Poiret Delano, deep rich crimson, petals tipped heavily with rose pink, an excellent flower, xxx..

Ora Dow, maroon tipped white, fine and showy, $x \times x$.

Osam Shudow, old rose and lilac, with shadings of yellow, makes this a most attractive dahlia. The flowers are enormous, on strong heavy stems...

Patrick O'Mara, the sensation of the Dahlia Show of the American Dahlia Society held in New York City September 20 . The flowers are 6 irches in diameter and borne on long, strong, erect stems. Thev are firmly set at right angles to the stems. The color is an unusually soft ard pleasing shade of orange buff, slightly tinged with rose. One of the most last ing cut-flower dahlias. Received American Dahlia Society's Gold Medal for best new variety in 1920 .

Perle d'Or, white, tall, stiff stem

Pierre Lebloud, its flowers are of very large size, produced on long wiry stems. In color, a bright ox blood red, heavily tipped white

Polsris, pure white decerative Dahlia, flowers of im mense size and perfect form. held well above the foliage on strong stems; habit of rlant is rathe dwarf, strong and vigorous; a flower with every good quality

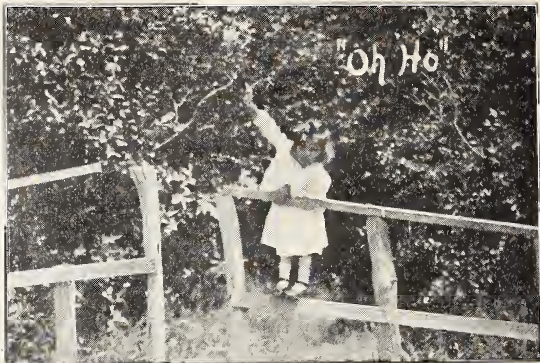

Pride of California, red decorative of good form and keeping qualities. Flowers freely on long stems well above the foliage $\ldots \ldots \ldots \ldots \ldots \ldots \ldots \ldots$

Princess Juliana, this has very long stems, very floriferous, a pure white of the more loose style of bloom, very good for vase $\ldots \ldots \ldots \ldots \ldots \ldots \ldots \ldots \ldots$. . . . . . . . perfect, upright habit that carries a mass of flowers on strong stems. Very attractive pure, rich pink shade, margined with sulphur. A beauty.......

Princess Pat, a 1920 introduction, A magnificent decorative of a glorious shace of old rose. Very large flowers, perfectly formed, growing well above the foliage on long erect stems A beautiful Dahlia for Exhibition and good keepirg qualities as a cut-flower. First Prize 1917 when seedling and winning prizes ever since ....................

Rosa Nell, the color is a clear bright iose, the flowers are large, and 1 consider it the best shaped Decora tive Dahlia l have seen, coming perfectly full and double until frost; good stems and habit; color is a rare one in dahlias, and attracts immediate attention while the form cannot be surpassed. This dahlia when it becomes krown, will be in every flower lover's garden. Stock limited, rot more than one

root will be sold to a cus omer ..............
San Mateo, a No'elty. Ore of the best Exhibition dahlias of true form. The largest and handsomest fancy or bi-color dahlia. A deep yellow, heavily striped and splashed scarlet, of great substance, fine

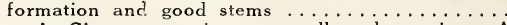

Sequoia Gigantes, an immerse yellow decorative.

very prolfic bloomer, with good stem $\ldots \ldots \ldots \ldots$
Shower of G-ld, a Novelty of brilliant yellow, deepening to soft apricot towards the center. A new type with slightly fluted petals. Large, strong stems and a color in demand ............ 2.00

Souv de Gustav Douzon, orange red of large size . . . .25

Souv de ma Mere, amber, suffused pink, passing to yellow at end of petals, $\mathrm{xxx} \ldots \ldots \ldots \ldots \ldots$

Souv de M. Silvent, yellow, lined and striped with carmine

Souv de Mme. Blonia, clear bright cerise, $\mathrm{xxxx} \ldots \ldots$.

Stunner (Dec.), a deep, substantial flower of large size. Color a rich, clear canary yellow ......... Sylvia, soft mauve pink, changing to white at center. g c, $x x x \ldots \ldots \ldots \ldots \ldots \ldots \ldots \ldots \ldots \ldots \ldots \ldots \ldots \ldots$ the

Tenor Alvarez, the Howers are produced upon long,
wiry stems, well above the foliage, which is remarkable for a Dahlia so large. The color combination is very pleasing and attractive but difficult to describe -violet-red very heavily striped and splashed lilac

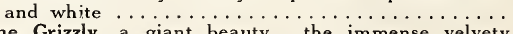

The Grizzly, a giant beauty. the immense velvety maroon blooms are of finest formation, with reflexed petals. Extra long. strong stems ...... 2.50

Theodore Vail, a very large bloom of old gold shading

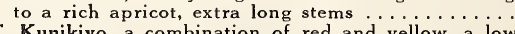

a red and yell grower, but a very free bloomer, with fine stem. 1.50

Ysleta, the coloring of this dahlia is very difficult to describe, being a blending of salmon, orange and coppery tints, the fully opened flower reminding one of the Herriot Rose, $2 \mathrm{t} / 2 \mathrm{ft} . \ldots \ldots \ldots \ldots \ldots \ldots$.

Zylpha (Hnwell), a sure prize winner. One of the largest of the Howell seedlings, and an unusually floriferous variety. Its color is red, shirred with carmine, and we unhesitatingly recommend it as one of the very best .................... 1.00 


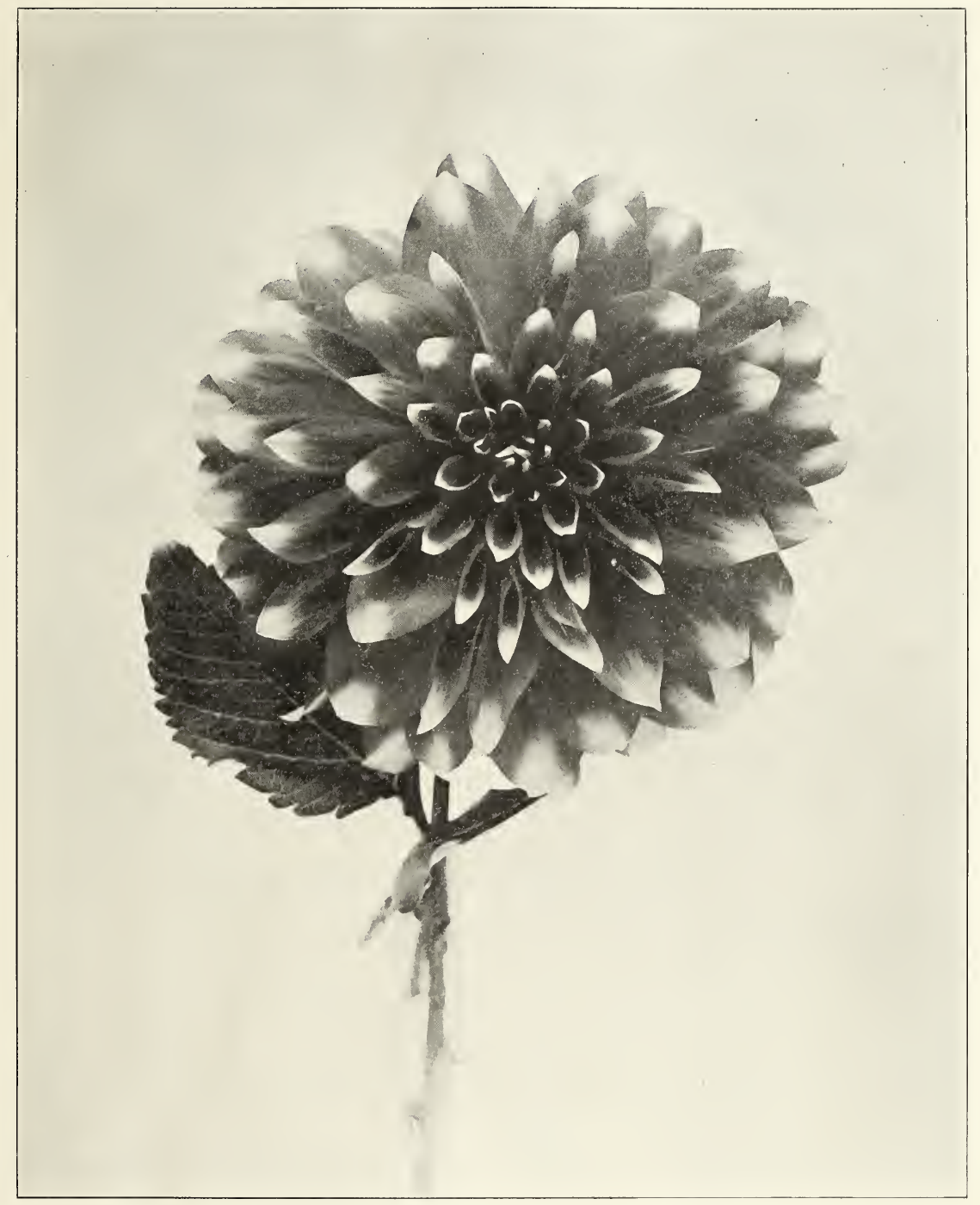

PRESIDENT WILSON A collosal beauty that words fail to do justice to. In our gardens it was "the great allure," and I doubt if any other Dahlia grown, with the single exception of Earle Williams, equals it in gorgeousness of coloring. A brilliant vermillion scarlet, evenly tipped white. Sometimes the flowers are too large for the long stems, and droop slightly. A really good exhibition and garden variety.

Field Grown Tubers $\$ 5.00$ each 


\section{PAEONY-FLOWERED DAHLIAS}

Prompted by the great popularity of the Cactus Dahlia, then so different from the stiff, ball-shaped Dahlias but only fitted for exhibition, lacking the grace and freedom to flower of the Single Dahlia, European hybridizers saw the possibility of a type suitable for both garden and cut-flower purposes.

By crossing the Cactus with the Single, and vice versa, they developed this new type now popular all over the world. These long stemmsd, semi-double Dahlias were grown in Holland, and sold as Half-double Giant Dahlias. Mr. H. Hornsveld, an Orchid specialist of Baarn, Holland, immediately saw their possibilities and collected the largest and most promising specimens. The great development and present value of the Peony-flowered type is due to him. After seven years of cross-hybridizing and developing (July, 1904), he was able to show the results at the meeting of the Dutch Horticultural Society at Rosendaal, where he exhibited four varieties, Queen Wilhelmina, Duke Henry, Baron G. de Grancy and Glory of Baarn. Here he received a first-class certificate of Merit, and the admiration and encouragement of growers and lovers of beauty. After Dusseldorf came Paris, Amsterdam, London.

The rich, golden yellow center, loosely arranged petals, large and fluffy, gives them a certain fascination and artistic appearance that none of the other types possess. They are favorite garden and cut-flower dahlias, producing abundantly and continuously. Stems are long and graceful, and their blossoms remarkably effective in bouquets.

Flowers are Semi-double, having two, three or more rows of broad, flat, loosely arranged rays or petals, surrounding an open center, which is usually a conspicuous golden yellow. The inner floral rays being usually curled or twisted, the outer rays either flat, or more or less irregular. Sometimes the rays are pointed, occasionally they curl and twist over the center, causing them to resemble the Chinese Peony, hence the name.

America, pure shrimp-pink, suffused with orange; ideal, erect stems

Andrew Carnegie, salmon pirk with bronze shadings.

Anny Doppenberg, fower of good size and almost full centered; blooms freely on long, stems. Lovely pale yellow with cream shadings. A most satis-

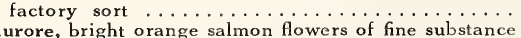

Aurore, bright orange salmon flowers of fine substance
held erect on long, extra stout stems. Early and free bloomer...

Autumn Glory, an immense flower of the true peony flowered type. The color is hard to describe; distinct shade of bronzy cinnamon, burnished with terracotta. Some of the flowers have a broad stripe of rich amber color, running the full length of each petal. Strong, robust grower with less foliage than usual; very long, graceful stem and a free and constant bloomer

Bertha Von Suttner, delicate salmon pirk, shaded yellow; quite double, of immense size; fine stems...

Bettws, grand $f$ swers of unusual form. Color a combination of old gold, rose and amber. Stems

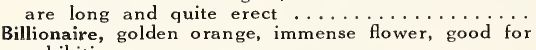
exhibition

Black Beauty, the biggest and blackest peony flower grown; wonderful stems $\ldots \ldots \ldots$..................

Blossom, immense flowers of white with a faint pink colorings seen in the fruit blossoms. A perfect exhibition flower; blooms held high above bush on long stiff stems and last for days when cut.

Caesar, yellow, fine

Cecelia, white, deep canary yellow in base of petals.

City of Portland, a clear, deep yellow of immense size, a very popular flower, won the prize as the largest bloom in the Palace Hotel Show .......4.00

Col. Cody, deep apricot, shaded buff, $\mathrm{xxx} \ldots \ldots \ldots .25$

Copper, flower of odd coloring; copper, shading to bronze. Splendid habit; free bloomer; good stem de la $\mathrm{P}$ aix, large salmon rose flower, tinted violet.

Cour de la Paix, large salmon rose flower, tinted violet.
Similar to 'Van Dyck' but stems are erect; very desirable dahlia

Cresm King, English, of the color its name denot... 1.00

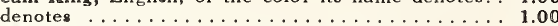

Creation, cherry red and golden bronze Peony...... 1.00

Dr. H. H. Rusby, immense yellow, shading to primrose

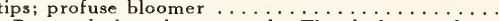

Dr. Peary, dark mahogany red. The darkest and one of the largest varieties in this type. A constant bloomer

Dusty Queen, deep velvety maroon, edged white, bright yellow disc, very stiff, long stems .............

Duchess of Brunswick, a distinct shade of bright apricot red, shaded orange; very free bloomer and stout stems

Edith Cavell, an enormous flower of old gold shaded

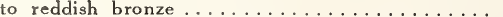

Elsa, fluffy cream white flowers, very large, standing high above foliage

Ethel May, golden yellow splashed rosy red
Flamingo, Holland, deep pink, stiff stems and rather

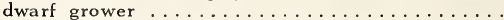

Frau Geheimsat Scheiff, one of the grandest of its color, large flower set on a long stiff stem, very floriferous, carmine salinon $\ldots \ldots \ldots \ldots \ldots \ldots \ldots \ldots \ldots \ldots \ldots \ldots$.

Geisha, orango red with yellow center, great flower eorge H. Mastick, Hybrid Peony. Large flowers of blackish maroon with lighter tips to the outer rows of petals. Remarkably free and constant in flowering. Fine erect habit and upright stems .......

Glory of Nykerk, rich violet purple, tinted crimsoncerise. Very large with stout stems; highly recom-

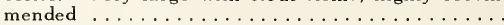

Goliath, the color is an intense, rich scarlet of twisted form. Blooms are of large size, quite full and held erect. Strong grower and good bloomer; an English

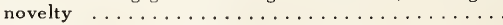

Georgeous, has everything that could be required in a dahlia, wonderful color of yellow shading to bright red, extra long stem, immense flower, and best of all its exceptionally good keeping qualities as a cutflower. Very tall grower . . . . . . . . . . . . . $\mathbf{5 . 0 0}$

Helen Baxter, rich amber yellow, $\mathrm{xxx} \ldots \ldots \ldots \ldots . .25$

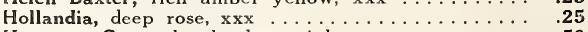

Hampton Court, lovely deep pink, xxx ..........

H. J. Lovink, beautiful Holland Peony-flowered Dahlia. Flowers large and produced upon exceptionally long wiry stems. The coloring is very delicate, white, daintily blending to lilac

Isa, very odd shape of light fawn pink, overlaid with amber. Good habit of growth, free bloomer and long, erect stems .................................

James C. Gill, giant new peony dahlia carried on extra strong, erect stems. Color is a striking, rich golden orange, variously marked with scarlet; very free bloomer and is highly recommended to all......

Jessie M. Williams, dove color shading to bronze and likac . Hybrid-peory dahlia of the greatest merit. The color is a most beautiful lemon yellow, changing to almost white at the tips. A large, attractive flower on very stout, erect stems. Plants are dwarf, needing no staking, tying, etc. A very lasting cutflower ..........

Kleopatra, chrome yellow, large and fine, $\mathrm{xxx} \ldots \ldots$

Lady Alla, a bright scarlet peony or duplex type of dahlia that blooms freely and constantly; long,

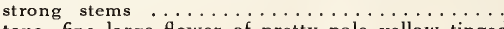

buff and lavender. Freely produced on the stoutest, erect stems. This new Holland creation is sure to be in great demand $\ldots \ldots \ldots \ldots \ldots \ldots \ldots \ldots \ldots$

Laura Barnes, beyond question one of the grandest peony dahlias ever introduced. Only words of praise for it from every source. lmmense beautiful

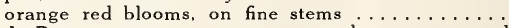

Lady Penzance, warm terra-cotta petals numerous and most elegantly formed, extra fine for cutting .... Liberty, soft scarlet, very large flowers on good stems; a very striking shade and flower .......... 1.00

Manheime, rich salmon, extra fine .......... .25 
Visitors often ask "Why are your flowers so beautiful?

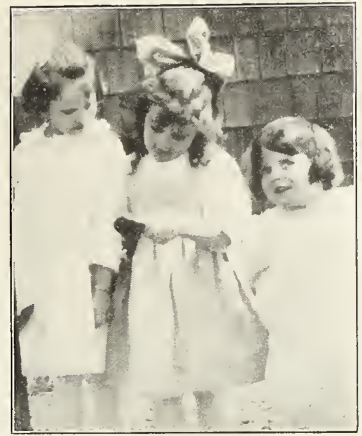

"Ils font la pluie et le beau temps."

Miss G. Keeling, pale rose $\ldots \ldots \ldots \ldots \ldots \ldots \ldots$

Mme. J. Coissard, body white, center of petals cream, each petal largely bordered with carmine red, marked with bright garnet, vigorous and flowers abundantly; considered the most beautiful yet grown of

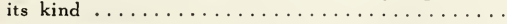

Mme. Van Bijstein, a very distinct and new shade, lilacblue throughout. Plants tall and sturdy, holding blooms well above the foliage. Large and fine....

Mrs. George Gordon, a delicate creamy-white flower of large size. The plant has a good upright habit of growth and is a free bloomer. One of the best

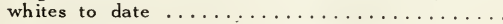

Mrs. Jack Green, Flowers of wonderfully fine formation; full and deep; of large size. Color a most

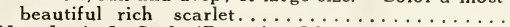

Mrs. Jessie L. Seal, (Peony). The very large flowers are a magnificent old rose color; and are held high above the foliage on fine long stems. An excellent cut-flower; a profuse bloomer ................
Mrs. T. G. Baker, the best white, $x x x x$

Natalie Mai, deep burgundy and maroon with gold suffusion of true peony type ............ 1.50

Paeonie, beautiful carmine rose $\ldots \ldots \ldots \ldots \ldots \ldots . \quad .50$

Polar Star, the purest white, and one of the finest to date. An early, free and constant bloomer; flowers are of large size on long, upright stems.........

Pride of Portland, a magnificent variety that is worthy of a place in the most up-to-date collection, where something really gorgeous is desired. Quite similax to the ever popular "Geisha" in color, but the yellow is brighter and the red is of a richer shade. It is more double than that old favorite, in fact, some blooms are almost of the decorative type. Without a doubt one of the largest dahlias we have ever grown, with stems in proportion, that hold the giant blooms well above the foliage, never failing to attract the attention of everyone. It is a healthy, robust grower, producing the immense blooms ear!y. freely and constantly all season $\ldots \ldots \ldots \ldots \ldots$.

Queen Esther, beautiful deep red of enormous size. good substance and long, strong stems. Stock

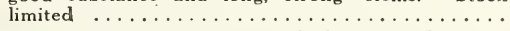

Queen Wilhelmina, largest and finest of the pure white sorts; excellent for decorative work and unsurpassed as a cut-flower. Blossoms produced upon long, graceful stems, well above the foliage. An immense, fluffy flower of pure glistening white, showing its beautiful golden-yellow center very prominently, which lends an additional charm to this most

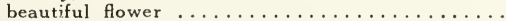

Sherlock Holmes, an ideal flower, possessing remarkable qualities; flowers beautifully formed and of excellent type. A beautiful shade of mauve .....

South Pole, a new, large white variety, rivaling "Queen Wilhelmina." It bears the blooms freely, well above the foliage, on strong, erect stems. A welcome ad-

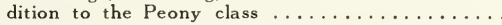

The Rosary, a cerise-pink bloom on extra long stem. Of robust growth, and good keeper as cut-flower. .

White Cloud, a very long stem, pure white ........

Zeppelin, the incomparable delicacy and richness of this most interesting variety has excited great comment. The color is the most beautiful shade of mauve-a very fascinating color. The perfection in form of this variety is ene of its greatest features.

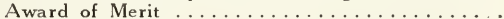

\section{SINGLE DAHLIAS}

Becoming extremely popular because of their simple grace, wonderful stems and adaptability to decorative effect both in garden and house. Open centered; for perfection of flower, eight petaled in circle. 25 cents each; $\$ 2.50$ per doz., except those priced.

Amazon, canary yellow, blotched deep carmine ....

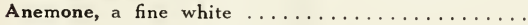

Bangor, bright scarlet, large $\ldots \ldots \ldots \ldots \ldots \ldots \ldots$

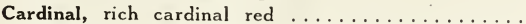

Cambridge, a large brilliant crimson, bold golden disc

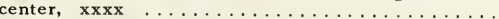

Climax, deep yellow, suffused red . . . . . . . . .

Crimson Century, glowing crimson ...........

Golden Glow, this is the most beautiful single we ever grew, of a wonderful autumn gold, shading terra

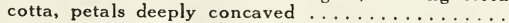

Isabella, white, speckled and striped crimson ...... Jack, fiery scarlet, golden yellow center, $x x x \ldots \ldots$ Maroon Century, deep crimson maroon ............ Merry Widow, gigantic flower of deep scarlet ........ Midnight, black maroon, $\mathrm{xxxx}$............................

Mascotte, deep rosy crimson, tipped with lilac, very

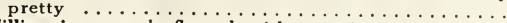

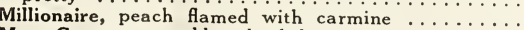
Mrs. Creevy, a golden buff beauty, unequaled for decorative effect as a cut flower

Newport Beauty, large flower of exceptional beauty. borne on long stems, being rich crimson shaded lighter, almost to a pink at the edges .........
Nora, scarlet slpashed yellow

Parable, purple tipped white $\ldots \ldots \ldots \ldots \ldots \ldots$

Pink Century, the largest of this class, and one of the

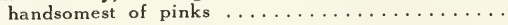

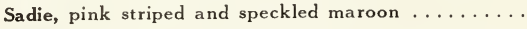

Sampson, one of the finest of the dark maroons ....

Scarlet Century, dashing scarlet and of large size..

Sensation, vivid vermillion, tipped heavily with snow

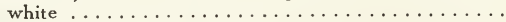

Snowdrop, the finest white $\ldots \ldots \ldots \ldots \ldots \ldots \ldots$

Terra Cotta, rich terra-cotta with delicate sheen of

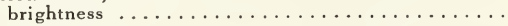

Twentieth Century, rosy crimson with white disc and

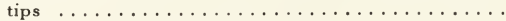

Union Jack, a very striking single dahlia of clear, vivid scarlet and pure white striped.$\ldots \ldots \ldots \ldots \ldots$

White Century, large, beautiful white flower .......

Yellow Century, canary yellow, large flower .......

Zonal, deep peach pink; deep, bright large disc of yellow, $\mathrm{xxx} \ldots \ldots \ldots \ldots \ldots \ldots \ldots \ldots \ldots \ldots$
Page Twenty-one 


\section{SHOW DAHLIAS}

This class is in all probability the oldest flower form of the dahlia and is therefore more universally known.

They are valuable for massing or making especial effect in borders. The advancement in this class has been very pronounced, giving greater depth of bloom on increased length of stem. They make a fine showy room decoration and will keep fresh longer and stand more handling than any of the classes.

Flowers globular or ball shaped, rather than broad or flat, full to the center, showing regular spiral arrangement of florets, with floral rays or petals more or less quilled or with their margins involute (rolled forward or inward) and rounded tip. (Dahlias of this type with flowers spotted variegated or parti-colored, were formerly classed as Fancy; a group no longer recognized.)

A. D. Livona, sea shell pink, $x \times x \ldots \ldots \ldots \ldots \ldots . . \ldots \ldots$

Agent, delicate soft pink .............. 25

Chas. Lanier, amber shaded buff, large, $\mathrm{xx} \ldots \ldots .25$

Clementine, an extra fine cutting variety, very long stem, good size bloom, pure white ..........

Client, deep velvety crimson, large, $x x x \ldots \ldots \ldots$

Dorothy Peacock, the flowers are of good size, exquisite form, great substance; the color is that beautiful clear, live pink that appeals to everyone ......

Emily, white suffused lavender .............25

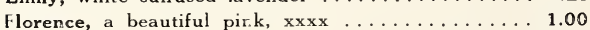

Florence Trantor, blush white, edged rosy purple . .25

Gold Medal, canary yellow, striped and flaked red. . .75

Gracchus, bright orange buff ............... .25

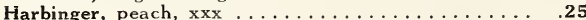

Ivanhoe, the color combination is exceedingly delicate -a beautiful snowy white, exquisitely edged with pinkish-lavender. The petals are perfectly cupped and the flowers are especially distinguished for their

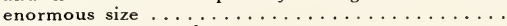

John. Walker, pure white, xxx

Joh Doehler, buff, speckled and striped with crimson

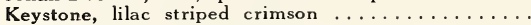

Leander, deep orange, $\mathrm{xxxx} \ldots \ldots \ldots \ldots \ldots \ldots \ldots$. . . .

Licy Fawcett, pale yellow, striped deep pink or light magerta. One of the best of this set. Very large and free flowering $\ldots \ldots \ldots \ldots \ldots \ldots \ldots \ldots \ldots \ldots$
Maude Adams, l cannot speak too highly of this variety. The color is a pure snowy white, very effectively overlaid clear delicate pink. Undoubtedly one of the finest of the Show type .........

Mr. Chamberlain, deep rich maroon ..........

Mrs. J. P. Smith, a vivid cherry blush over a rich crimson, the largest true type show dahlia yet

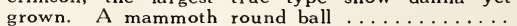

Mrs. Saunders, yellow, tipped white .........

Mrs. Wm. Slack, blush, white edged purple ......

Norma, orange shading to buff, $\operatorname{xxxx} \ldots \ldots \ldots \ldots$

Nugget, scarlet over yellow, $\mathrm{xxxx} \ldots \ldots \ldots \ldots \ldots$

Orlando, golden tan with rose back, $\mathrm{xxx} \ldots \ldots \ldots \ldots$

Penelope, white with soft lavender center ........

Puritan, white $\ldots \ldots \ldots \ldots \ldots \ldots \ldots \ldots$

Queen of Autumn, orange buff, a grand flower of large size, on fine stem, $x \times x x \ldots \ldots \ldots \ldots \ldots \ldots$

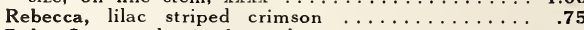

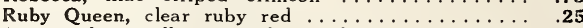

Sunset, deep yellow tinged on edges with orange.. .25

Susan, blush pink, g $\mathrm{c}, \mathrm{xxx} \ldots \ldots \ldots \ldots \ldots \ldots \ldots .25$

Susan Wilson, butter yellow, each petal tipped with carmine red, grand for cutting, g c, xxxx ......

Tom Jones, cream yellow, edged and suffused, bright

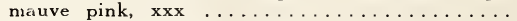

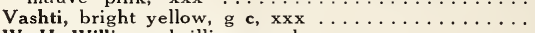

W. H. Williams, brilliant scarlet, $\mathrm{xxx}, \mathrm{g} \mathrm{c} \ldots \ldots \ldots$

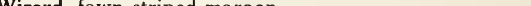

Yuban, a fine tan, striped and speckled rcd, xxxx. 1.00

\section{HYBRID SHOW or COLOSSAL DAHLIAS}

This is a type of Dahlia having characteristics of both the Decorative and Show types.

The flowers are fully double, broadly hemispherical to flatly globular in form, loosely built so spiral arrangement of florets is not immediately evident; floral rays broad, heavy cupped or quilled, with rounded tips and involute margins.

Acquisition, an exquisite shade of deep lilac. Very large with cup-like petals. Especially good for cutflower purposes ..................

A. E. Johnson, a perfect example of the Giant-flowering type. The plants are strong and sturdy, with good habit of growth. The ground color of the bloom is white or light blush, overlaid with a clear rose-pink

American Beauty, this champion Dahlia is a seedling from the well-known French variety, "Le Colosse," being almost identical in form, shape and size. The flowers are of gigantic size and are produced on long heavy stems, well above the foliage. The color of this acquisition is a gorgeour wine-

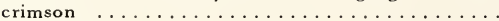

Anna Rehorst, H. S., very large flower of deepest shade

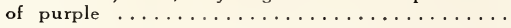

Eetiy Bird, (Seal), a wonderful dahlia. There is no other dahlia of its lovely soft pink coloring. The flowers are very large, of a perfect Hybrid Show Type, without the stiffness of the Show Dahlia, and keep unusually long when cut. We call this California's finest production $\ldots \ldots \ldots \ldots \ldots \ldots$

Clara Seaton, H. S., an enormous flower of rich golden bronze or apricot in color. Very attractive and

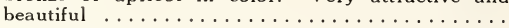

Dr. J. P. Kirkland, dark velvety crimson; large. Stems long and wiry. "Plants are very tall and sturdy.

Dreer's White, an excellent Dahlia for garden effect and hedges; plants are very strong and vigorous, making ideal bushy specimens, averaging 3 feet in height. Color, a pure, glistening white .......
Dreer's Yellow, a beautiful new Colossal Show Dahlia of perfect form; stems long and straight, carrying the blooms well above the foliage. The flowers form a perfect ball, often measuring 7 to 8 inches in diameter. Color, a rich, sulphur yellow ........

D. M. Moore, in this offering we have one of the best "nearly black" varieties to date. It is a rich, deep, velvety Victoria-lake, which is a shade deeper than deep maroon, the nearest approach to black to my knowledge. A mammoth fower produced

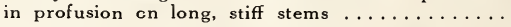

Estelle Christy, one of the best yellow Dahlias of this type ever introduced. The color is the purest golden-yellow, with no shading whatever. The size, color, length of stem and habit of growth make the above statement no exaggeration whatever. A

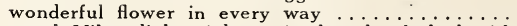

General Miles, light violet striped and splashed with purplish magenta. An enormous, large flower borne on long stout stems. The very best variegated show Dahlia in existence ........... 1.00

Grand Duchess Marie, blooms in profusion. Stems from 12 to 18 inches in length; cclor is very striking rich buff overlaid orange; reverse petals pink.

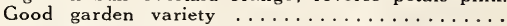

Lily P. Hathaway, a new Hybrid of the $\ddot{\text { highest merit. }}$ The coloring is a clear lemon-chrome, blending to deep orange towards the center, giving a general impression of light, orange-yellow. The plants are very sturdy and robust, with long, strong stems, and luxuriant foliage. One of the freest bloomers grown, making it a magnificent variety for the gar-

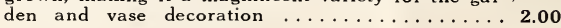




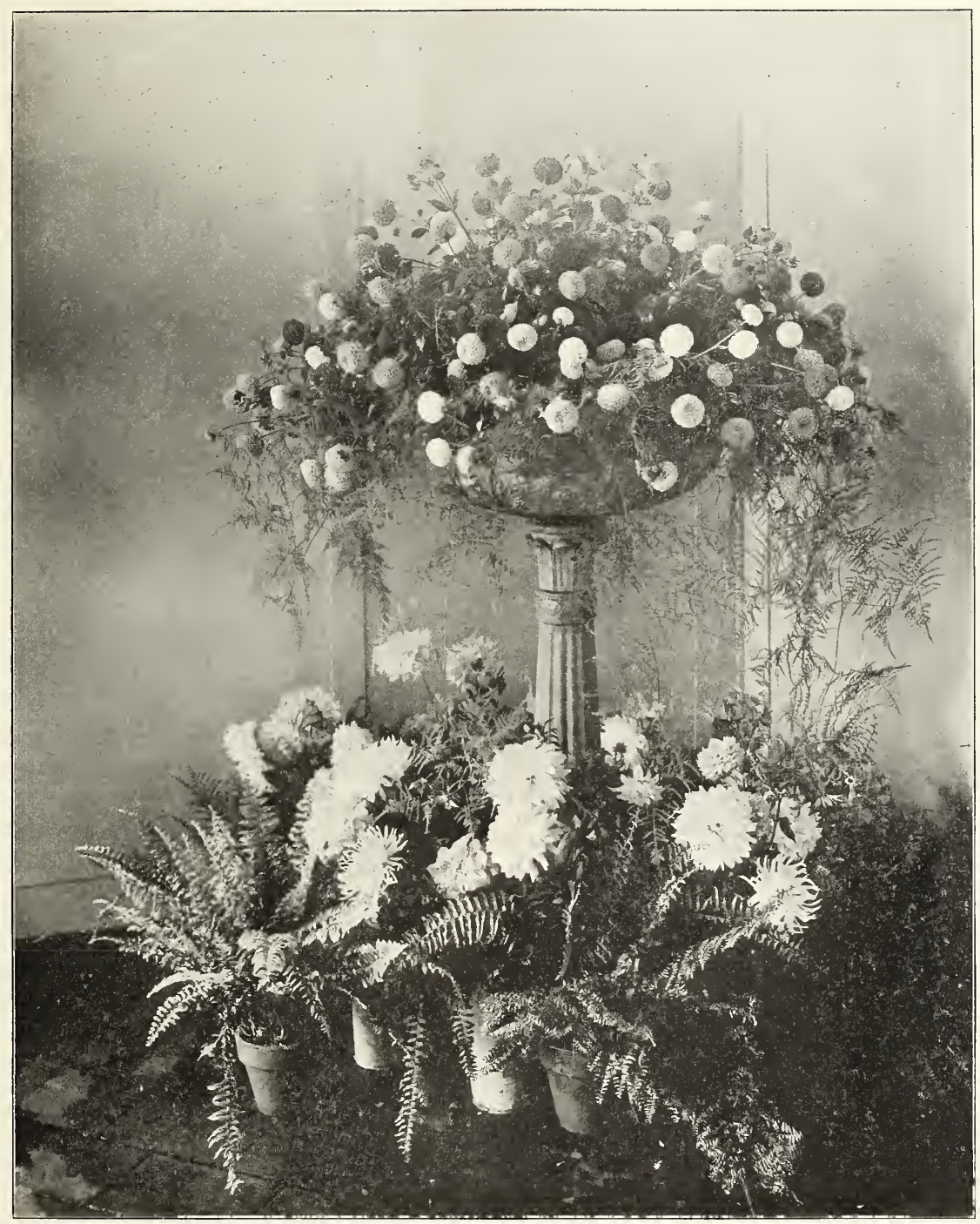

Our vase of Pompons that won 1st prize at the eshibition of the A. D. S. at the Pennsylvania Hotel, Sept., 1921 


\section{Hybrid Show or Colossal Dahlias, (Continued)}

Mme. Marze, a grand, white Colossal variety of perfect form, and immense size ...............

Vivian, large and of beautiful colorings. Center of blossom dark magerta, the ir side of the petal being much lighter cerise or jacquemizot. A large and excellent Dahlia
.50
W. W. Rawson, pure white overlaid with amethystblue. This wonderful combiration gives it the appearance of delicate lavender .............

Yellow Duke, a splendid primrose-ycllow of sood .50

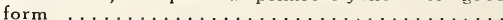

\section{THE POMPON OR BOUQUET DAHLIA}

Named from the French word signifying ornament for headdress, in military parlance "tuft," because of its resemblance to the ball of wool worn on the shakos of the Voltigeurs in 1800 and adopted later by English regiments, changing into the shaving brush adorning the headgear of the French infantry of the line in 1850 . The name of this variety has many variations, Stredwick insisting on Pompom, West Pompone, and one of our American growers Ponpon. 7 his is the best all-round class for every purpose, exceedingly floriferous, urbeatable for a torder because of its low growth-about 2 feet-and closely formed bush, unexcell d for Bouquet and vase work, and running the range of every color shade found in the larger classes. We are great rooters for this class and believe we grow more varieties of it than any other grower.

Flowers of this type for show purposes should be double ball shaped rather than flat, full to centre, petals quilled or with rolled in edges, rounded tops and less than 2 inches in diameter. Except where noted, $25 \mathrm{c}$ per tuber; $\$ 2.50$ per dozen.

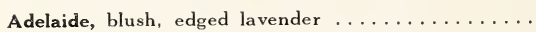

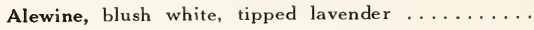

Amelia, pale pink, white center, $\mathrm{xxxx} \ldots \ldots \ldots$

Annie Doncaster, yellow base, suffused pearly pink.

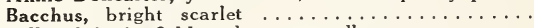

Belle of Springfield, red, very small $\ldots \ldots \ldots \ldots \ldots$

Blatrochen, blood red, rose points $\ldots \ldots \ldots \ldots \ldots$

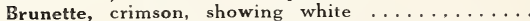

Cardinal, a novelty of German origin, intense fiery scarlet, long stem $\ldots \ldots \ldots \ldots \ldots \ldots \ldots \ldots \ldots \ldots \ldots \ldots \ldots$

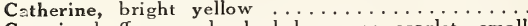

Corsair, buff ground, shaded orange scarlet, small

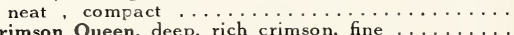

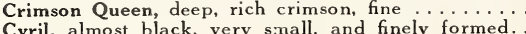

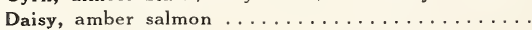

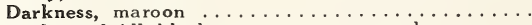

Darkest of All, black maroon, xxxx, grand ........

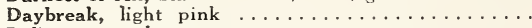

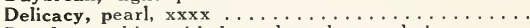

Dewdrop, white with lavender edges and tips ........

Dr. Jim, purple, shaded white, $\operatorname{xxx} \ldots \ldots \ldots \ldots \ldots$

Elaine, pure white $\ldots \ldots \ldots \ldots \ldots \ldots \ldots \ldots$

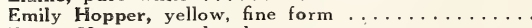

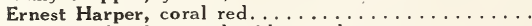

liurydice, blush tipped with purple, $\mathrm{xxxx} \ldots \ldots \ldots$

Eva, a fine formed white . . . . . . . . . .

Fairy Queen, sulphur yellow edged pink coral, xxxx..

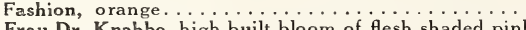

Frau Dr. Knabbe, high built bloom of flesh shaded pink Girlie, pinkish mauve, splendid ..................... George Ireland, a very perfect little flower of dainty

Gra's Am Wein, soft amber shaded cerise ........

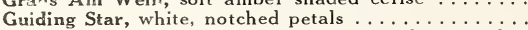
Hed-vig Pollwig, a glorious Pompon, red with white

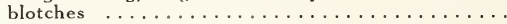
Hiawatha, deep, blackish maroon crimson, $\mathrm{xxxx} \ldots$. Hilda Searle, yellow tipped red $\ldots \ldots \ldots \ldots \ldots \ldots$ Ideal, clear yellow, xxxx $\ldots \ldots \ldots \ldots \ldots \ldots \ldots$ Isabel, vermillion . . . . . . . . . . . . . . Janet, old gold, a beauty . . . . . . . . . . Jeseica, amber edged red

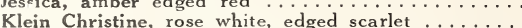

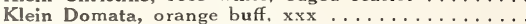

Leibe Klein, delicate rose lilac, white center, $\mathrm{xxx} \ldots$.
Leila, golden yellow, mottled crimson ........

Little Beauty, shrimp pink ....................

Little Beeswing, golden yellow, tipped cherry red. . .

Little Dorothy, creamy white, generally marked with reddish-orange; extra free bloomer ...........

Little Bessie, cream white $\ldots \ldots \ldots \ldots \ldots \ldots \ldots$ Little Mary, dark crimson with darker center, xxxx.. Marguerite, deep rose, $\mathrm{xxx} \ldots \ldots \ldots \ldots \ldots \ldots$

Mars (Ware), bright scarlet, $\mathrm{xxxx} \ldots \ldots \ldots \ldots \ldots$ Mary Clift, light maroon $\ldots \ldots \ldots \ldots \ldots \ldots \ldots$

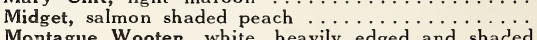
Montague Wooten, white, heavily edged and shaded

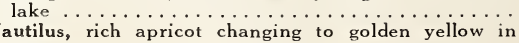
Nautilus, rich apricot changing to golden yellow in
centre Nerissa, soft rose, tinted silver, $\mathrm{xxxx} \ldots \ldots \ldots \ldots \ldots$

Nora Reynolds, Indian red, e g c, xxxx .......... Phoebe, orange scarlet, fine $\ldots \ldots \ldots \ldots \ldots \ldots$ Portia, deep mauve, shaded pink, each petal tipped with silver and having silver center, $x \times x x \ldots \ldots \ldots$.

Pride, dark crimson-scarlet; very perfect form ....

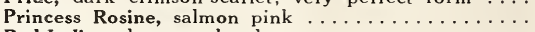
Red Indian, deep coral red . . . . . . . . . . . . Rival, flame color, a gem for cutting ...........

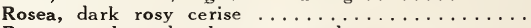

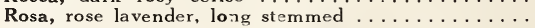

Rosebud, rose lilac and white, $\operatorname{xxxx} \ldots \ldots \ldots \ldots$

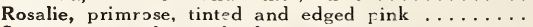
Santoy, pure white, edged carmine, xxxx $\ldots \ldots \ldots$

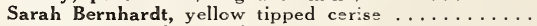
Scarlet Gem, a fine scarlet, $\operatorname{xxxx} \ldots \ldots \ldots \ldots \ldots \ldots$

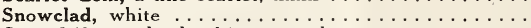

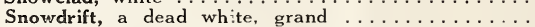
Sunbeam, a flaming crimson scarlet, $x \times x \ldots \ldots \ldots$. Sunshine, a vivid scarlet $\ldots \ldots \ldots \ldots \ldots \ldots \ldots$

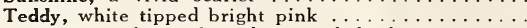
Tiny Tim, soft peach pink, one of th $₫$ best $\ldots \ldots \ldots$ Tom Borrowdale, rosy laverder . . . . . . . . Tommy Keith, red, tipped white $\ldots \ldots \ldots \ldots \ldots \ldots$ Tulla, wine crimson, wonderful bloomer ........ Vivid, bright orange scarlet .............. Winifred, lioht ground, heavily edged pale purple.. Whisper, yellow edged red, $\mathrm{xxx} \ldots \ldots \ldots \ldots \ldots$ Yellow Bird, lemon yellow, $\mathrm{xxxx}^{\ldots} \ldots \ldots \ldots \ldots \ldots$ Zoe, clear yellow, sometimes tipped white ......... 


\section{THE GLADIOLI}

This flower under good treatment responds quickly with so little effort, that one should have no excuse for not producing flowers of highest quality. The bulbs will flower in ten to twelve weeks from planting and by different times of planting one can have a long and continuous season of bloom.

We advise the planting of the corms not less than five inches deep and for the larger ones about six inches. Keep your soil well cultivated and do not plant in shade or where they cannot have plenty of sunlight.

In the fall when the foliage shows maturity, by turning yellow, they should be lifted, the tops cut off and the bulb laid in a dry, airy place for a week or ten days to cure. The old corm can then be removed and the new one put in boxes or bags and stored in a dry, cool, frost-proof place for the winter.

We have added to our list many new varieties, - most of them chosen upon their merits, as to beauty, growth and production, and we consider all which we offer here worthy of cultivation.

\section{Each Doz.}

Adaline Patti, a very large flower and a very dark violet color ...............\$ .50 $\$ 5.00$

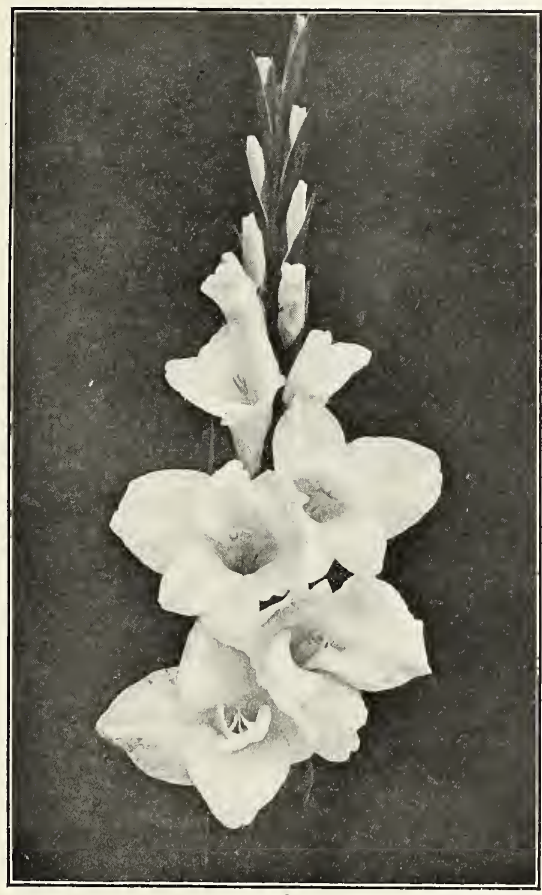

ALBANIA

(Kemp, 1921)

First Prixe Boston and New York, August, 1921.

This the the most pleasing white variety we have yet seen. The flower is wid open, four inches and over in diameter, petals are broad, with well rounded tips and beautifully crimped edges, making a beautiful finish. The back-ground is of the purest glistening white, with very faint light pink mottling, which is noticeable only on close observation. To all intents and purposes it is a pure white. The flowers are well placed on the spike and close enough together to obliterate spaces between the flowers, making an ideal and the best whit foruse in floral design work ever originated. Five flowers open at a time, and a splendid keeper when cut. Height four feet, 14-16 flowers to the spike, very healthy and a bountiful producer of good growable bulbets.

$\$ 1.00$ each, $\$ 10.00 \mathrm{doz}$.
Arizona, fine dark pink, with dark maroon

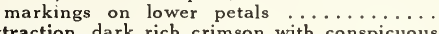
Attraction, dark rich crimson with conspicuous

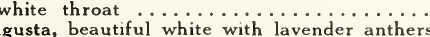
Augusta, beautiful white with lavender anthers
Alice Tiplady, a beautiful orange saffron yel-

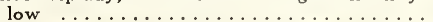

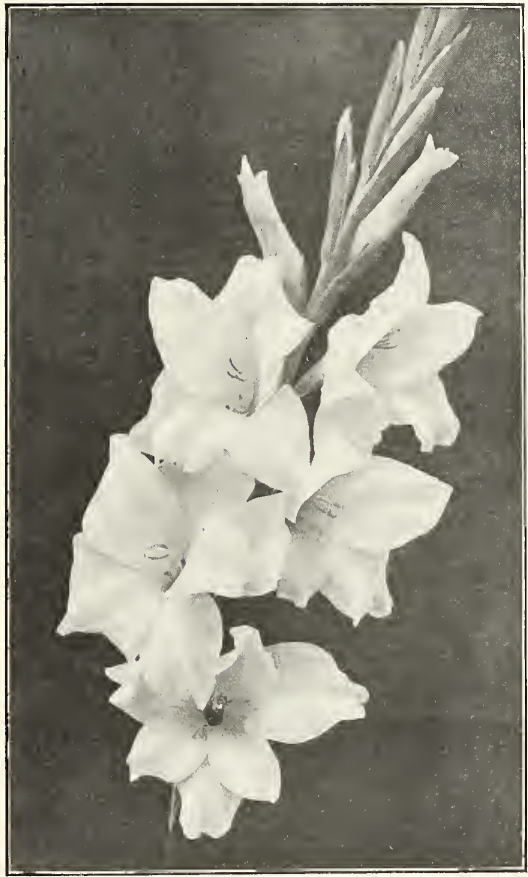

EARLY SNOWFLAKE

(Kemp, 1921)

First prize Boston, Silver Medal New York, August, 1921.

A very tall-growing variety, attaining a height of five feet and over, and often producing 23 large, perfect lily like flowers to the spike, many of them six inches in diameter. The color is a rich creamy white, delicately tinted and flaked rose, with tinge of yellow in the throat. blended with delicate rose feathering on rear half of lower petals. One of the showiest varieties for garden and house decoration, resembling a large lily rather than a Gladiolus. A splendid forcing variety, and when grown under glass all flaking of petals is absent. Heavy yielder of large, plump bulbets that grow.

$\$ .60$ each, $\$ 6.00$ dozen. 
Alice Carey, the flower is large, well expanded and of purest white excepting a small and

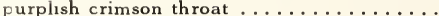

America, lavender pink, large flower, most popular commercial variety $\ldots . \ldots \ldots \ldots \ldots$. Amethyst, a solid formed flower of a deep amethyst color, slightly suffused rose ...

Anna Eberius, cerise purple, throat deeper shade, very large flower ............

Aviatrix, (Kemp). Large, fine flower. A delicate shade of pale yellow, much darker and brighter in the throat; fine pencilings of pale rose occurs in the throat and dashes of the same hue at the ends of the three under petals. Five flowers open at once on a very tall stem. Worthy of a place in every gar-

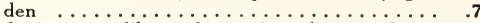

Badenia, pure lilac color and g glorious flower 2.0020 .00

Baron Hulot, rich purple with a bluish tinge flowers are of medium size, but of graceful

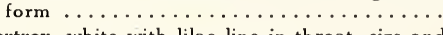

Bertrex, white with lilac line in throat, size and form of America. A fine white ..........

Blanche, the finest white of the Childsi strain, large flowers with but few markings of pale rose

Blue Bird, large blue flowers shading to white

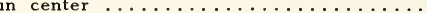

Blue Jay, blue, and one of the best, being very vigorous $\cdots \cdots \cdots \cdots \cdots \cdots \cdots \cdots$ Bright Red, a very brilliant bright red, solid 3uttercup, (Kemp). One of the best Primulinus Hybrids yet introduced. Deep buttercup yelyellow, small red stripe in middle of lower petals, medium size and early. Prize winner in Boston and New York Shows ...........

Bordeaux, (Alkemade). Named after that famous wine which it resembles in color; early and prolific

Charlemagne, French introduction of the giant type with a very open large flower carried on a massive spike; color is sunrise red, flaked darker and marked with large creamy white blotches, densely dotted with purple carmine …… (Vos). Bright cerise, red blotch, bordered by light yellow on lower petals; large, well expanded flower ......

Chicago White, pure white with a small magenta stain in the throat; quite early .........

Clear Eye, tall, robust, strong grower, long spike, broad dark green foliage, a rich dark scarlet with a white center; broad flower of

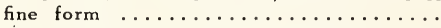

Conspicuous, light blue, darker spot with yellow center on lower petals. Called the Pansy

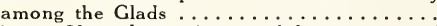

Crimson Glow, deep crimson, of the most rugged constitution. The best shipping red

Dawn, the most beautiful shell pink gladioli yet offered; graceful spike of magnificent

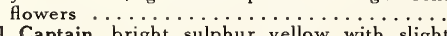
penciling of red on lower petals; flowers are large and well open, spike is straight and strong and the leaves are very wide; the entire plant is exceptionally vigorous.

Electra, brilliant scarlet and a very large flower

Empress of India, rich dark red, with a brownish tinge; a rare and beautiful shade of color. .

Estella, one of the largest of Gladiolus, wide open flower, color dark pink with light blotch,

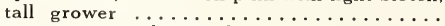

Europa, snowy white without a trace of color; the finest pure white l have yet grown or velyn Kirtland, (Mrs. Austin). One of the finest of Glads! Tall, straight but slender spike. Color a beautiful shade of rose pink darker at the edges, fading to shell pink at the center with brilliant scarlet blotch on lower petals

E. J. Shaylor, (Kunderd). Deep rose pink, tall strong spike with large blooms

.151 .50

$.50 \quad 5.00$

$.20 \quad 2.00$

$.50 \quad 5.00$
Excelsior, pure white, small flower, but immense spikes four feet high, generally has two or more spikes ................

Faust, (syn. Bleriot, Harvard, George Paul). rlowers of large size, well arranged on a spike of four feet high, color deep velvety

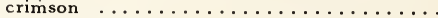

Flora, (Velthuys). in color second only to Golden Measure and in some respects a better variety. The best golden yellow pro curable at a reasonable price and should be in every high grade collection .........

Giant White, (Kunderd). An extra large white with slight markings on lower petals Glory, (Ruffle), the opening buds are of a soft creamy tint, edged with pink, but as the flowers expand, the ground color changes to a rich ivory white suffused with pale lavender, which is deeper on the edges. The lower petals are buffish with a pale crimson stripe through the center; the throat is penciled with buff and crimson; the spike straight and strong, flowers large $\ldots \ldots \ldots \ldots \ldots$

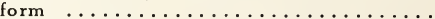
Glory of Noordwyk, magnificent yellow of wonderful size and grace ...................... Golden King, (Black). Deep golden yellow, intense crimson blotch in throat. Flower Golden Measure, the most wonderful spike and bloom, and the only pure yellow ........

Gov. Hanly, rich cardinal, a little deeper shade in the throat; flowers are of medium size but

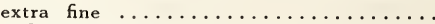

Gretchen Zang, exquisite rose pink $\ldots \ldots \ldots \ldots$ Halley, salmon pink, with creamy white blotch;

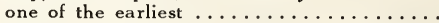

Herada, pure mauve with deeper markings in throat. Very large flowers, tall straight spike. Wonderful bulbet producer. Beyond any doubt the finest gladiolus in its color...

Haubenstaufen, white tinged soft pink, scarlet

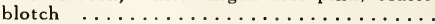

Hohenzollern, salmon pink, large chocolate

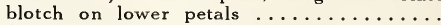

Hollandia, the flower spikes attain a height of about four feet, charming pink shaded with a

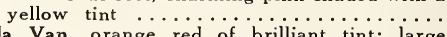

Ida Van, orange red of brilliant tint; large wide open flowers; spike is strong and straight; showy and attractive ..........

Ivory, ivory white with light markings in throat

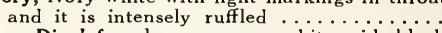

Jean Dieulafoy, large creamy white with blush tinge and a maroon blotch ..........

Klondyke, primrose yellow, lightly tinged with red on the edge of petals; compact grower

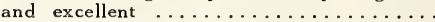

Liebesfeuer, brilliant scarlet; very fine flower.

Lily Lehman, ivory white; extra good for all

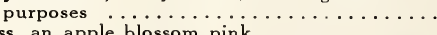

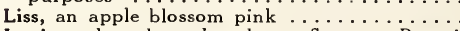

Louise, clear lavender, large flower. Beauti

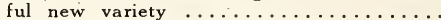

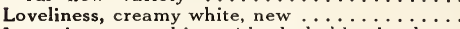

Lucretia, rosy white with dark blotch alway two or three flowers spikes to the bulb, five feet long, the best market variety, early and

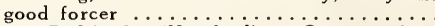

Mary Pickford, (Kunderd). Cream white, throat finest soft sulphur yellow .......

Meadowvale, pure white, a touch of vivid crimson in the throat and three lower petals

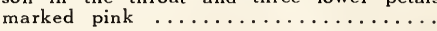

Meteor, glowing scarlet orange, blotched with blood red; a very large flower, also ex

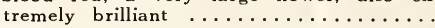

Midnight, in color a dark reddish brown with a peculiar marked throat with cream color; while not a large flower yet it is valuable

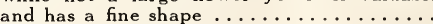

Mongolian, a superb yellow with a slight tinge of pink in the throat; its flowers are borne on a long spike and are not only large but

very graceful; med. early ........... 1.0010 .00

$.10 \quad 1.00$

$10 \quad 1.00$

1.0010 .00

$.06 \quad .65$

4.0040 .00

25

2.50

05

.50

.15

1.50

$10 \quad 1.00$

$.10 \quad 1.00$

$.10 \quad 1.00$

$.10 \quad 1.00$

$.20 \quad 2.00$

$.10 \quad 1.00$

$.10 \quad 1.00$

.252 .50

$.10 \quad 1.00$

$.25 \quad 2.50$

$\begin{array}{ll}.75 & 7.50\end{array}$

$.25 \quad 2.50$

$.05 \quad .50$

$.35 \quad 3.50$

$.10 \quad 1.00$

$\begin{array}{ll}50 & 5.00\end{array}$

$.25 \quad 2.50$ 
Mrs. Dr. Norton, pure white shading to pink at edge of petals; a beautiful novelty and sure winner wherever shown ..........

Mrs. Francis King, a true flame and in all situations it is very effective and grand; a good grower and bears very large well

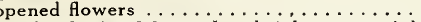

Mrs. Frank Pendelton, Jr., bright rose pink, shading to a deeper tint toward the center of the petals, the lower petals blotched with rich carmine; flowers are large, well opened and of graceful form; spike straight and strong while the growth is very vigorous.

Mrs. John Turnbull, (Kemp). Lavender pink with red feather-like markings in the throat.

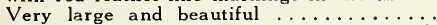
Muriel, a beautiful orchid shade with purple

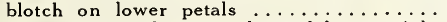

Myrtle, one of the most beautiful rose-pinks yet produced $\ldots \ldots \ldots \ldots \ldots \ldots \ldots \ldots \ldots$

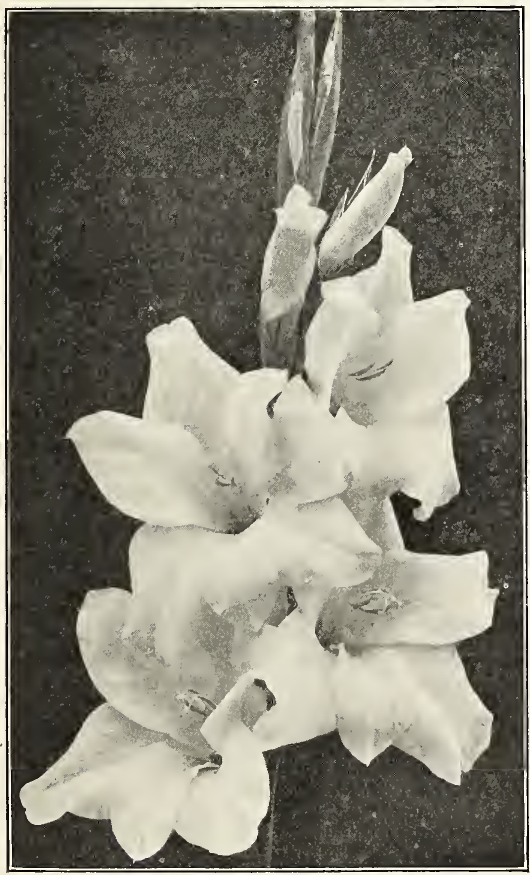

PINK WONDER

(Kemp, 1921)

First prize Boston and New York, August, 1921.

This is a wonderful Gladiolus, the largest and finest pink variety ever introduced. It is a very strong, vigorous grower, attaining a height of 4 1-2 feet, often producing 17-19 blooms to the spike; four and five massive flowe-s open at one time, many of them measuring $61-2$ inches in diameter, very decorative for garden and house, and splendid for forcing, producing exhibition blooms of the highest quality. The color is a shade lighter than Panama, yellow shading at base of lower petals overlaid with rose feathering. A very pleasing color combination that is much admired by everybody. Bountiful producer of sound bulbets that will grow. Pink Wonder is indeed a wonderful glad in every respect, and is soon to become one of the most popular varieties ver offered.

$\$ 1.50$ each, $\$ 15.00$ dozen
Niagara, Nanking yellow, there is nothing to equal this variety in its shade of color; very large flower and very strong straight spike

Nora, light blue with little darker spot in

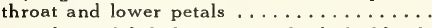

Orion, beautiful light rose with dark blotch, strong and just lovely for cutting .......

Panama, magnificent pale pink and a very large, and well arranged flower and one of

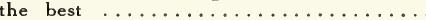

Peace, beautiful white with pale lilac featherings; large flowers borne on long strong

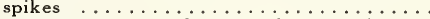

Pink Beauty, not only one of the earliest to bloom but as good in flower and spike and color as any; a fine pink and a long spike

Pink Perfection, pure apple blossom pink,

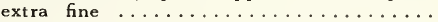
Pink Progression, this is a companion to $\mathrm{Pink}$ Beauty, being a light shade of true rose;

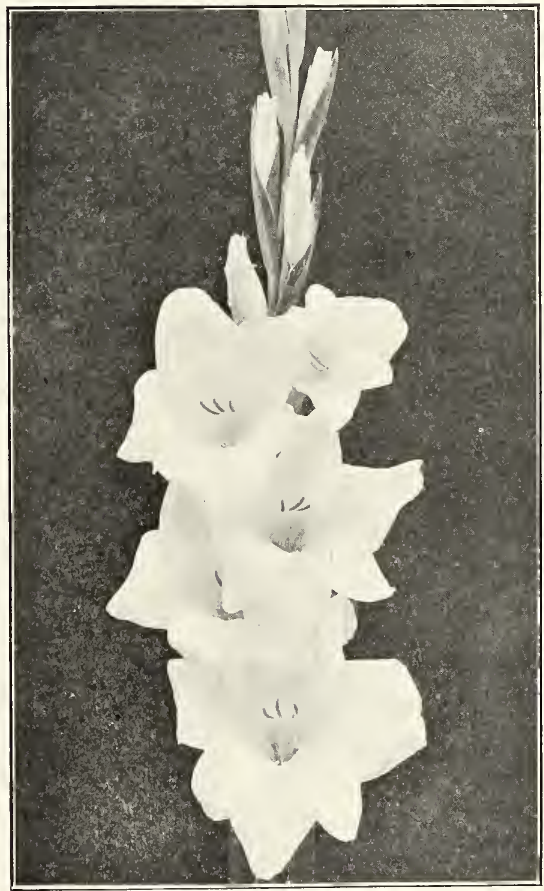

WHITE WONDER

(Kemp, 1921)

First prize Boston, Silver Medal, New York, August, 1921.

This magnificent white is a descendant of the well-known and justly popular variety Mrs. Francis King and is endowed with all the good qualities of that splendid old variety. In growth it is fully as robust as King and of equally good habit in every respect. The flowers are pure white, without any markings in the throat, wide open, and often measuring up to $53 / 4$ inches in diameter, well placed on the spike, five to six open at a time. Like $\mathrm{King}$, it is a very heavy producer of large bulblets that will grow. This great white is a splendid forcing variety and will soon become the leader in the white section for garden culture and for forcing under glass.

First size bulbs, $\$ 1.50$ each. 12 for $\$ 15.00$ 
Pride of Goshen, bright salmon pink with flowers of large size and well opened; the petals are heavily ruffled and the plant is tall and vigorous $\ldots \ldots \ldots \ldots \ldots \ldots \ldots \ldots \ldots \ldots \ldots \ldots \ldots$. $\ldots \ldots$.

Princeps, brilliant scarlet, intense shading in the throat and broad white blotches across the

lower petals ... . . . . . . . . . . . . . . . . .

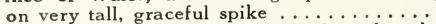

Queen of the Whites, pure white forced under glass, cold; strong long spikes and each bulb produces two long stems with 10 to 12 flowers open at one time; said to be better and earlier than the variety Europe ...........

Red Amaryllis, brilliant blood red flower of giant size borne on a plant of medium height; a most gorgeous and showy red ..........

Red Canna, brightest of crimson pink and with

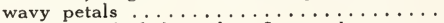

Scarsdale, pinkish lavender; flowers large on a tall and straight spike $\ldots \ldots \ldots \ldots \ldots \ldots$

Schwaben, this is a very fine novelty, its spikes are very strong and every bulb produces more than one spike at one time; the flowers are very large and the color is fine canary yellow with a brown carmine blotch in the

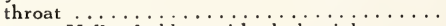

Senator Volland, blue with dark violet spot, margined with yellow .............

Sulphur King, clear sulphur yellow, suaight and strong spike $(\dot{\mathrm{K}} \ldots \ldots \ldots \ldots \ldots \ldots \ldots$ Sweetheart, (P. H.) (Kemp). Prize winner variety; color, a light cream, golden yellow markings on lower petals with faint rose feathering at the base. Flower is wide open four inches and over in diameter and well placed on spike ...............

Snowboy, tall and stately, pure white, usually has only one very beautiful blotch on lower petal; a large flower of unrivalled beauty and

$.10 \quad 1.00$

.25

$.50 \quad 5.00$

$50 \quad 5.00$

202.00

$.10 \quad 1.00$

.202 .00

.151 .50

$25 \quad 2.50$

.60 purity $\ldots \ldots \ldots \ldots \ldots \ldots \ldots \ldots \ldots \ldots \ldots \ldots$

Taconic, bright pink, splashed with lighter tints and lower petals with blotch of crimson ending in a thin stripe of yellow ...........

.0010 .00

$.10 \quad 1.00$

Velvet King, a very dark scarlet and extra good $.10 \quad 1.00$

Wamba, pink with rose throat; immense orchid-

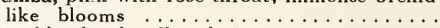
War, blood red, tall and vigorous ..........

White Giant, pure white and very large flowers,

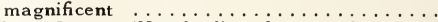

White Glory, (Kunderd). Large white with beautiful iris blue throat ............

White King, as tall a grower as Glory and in color a very rich sulphur white, splendidly suffused and nicely marked on lower petals

Willy Wigman, blush white color with dark car-

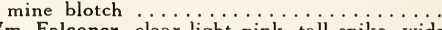

Wm. Falconer, clear light pink, tall spike, wide open flowers; a thoroughly proven variety

Yellow Bird, tall, straight spikes of a very pleasing shade of yellow and has heavy dark

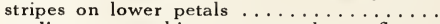

Zeppelin, pure white, a very large flower, truss fully four or more feet high and is a very robust, strong grower . . . . . . 2.0020 .00 Special Mixture, consisting of almost everything. Named varieties, unnamed seedlings, Primulinus Hybrids, etc., probably the most com-

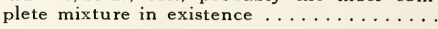

\section{SPECIAL OFFER}

To popularize this Beautiful Flower, we will send 100 first size corms that will delight you with their beautiful blooms for $\$ 4.00$ prepaid to any address.

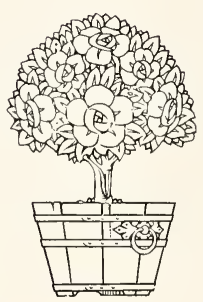




\section{PEONIES}

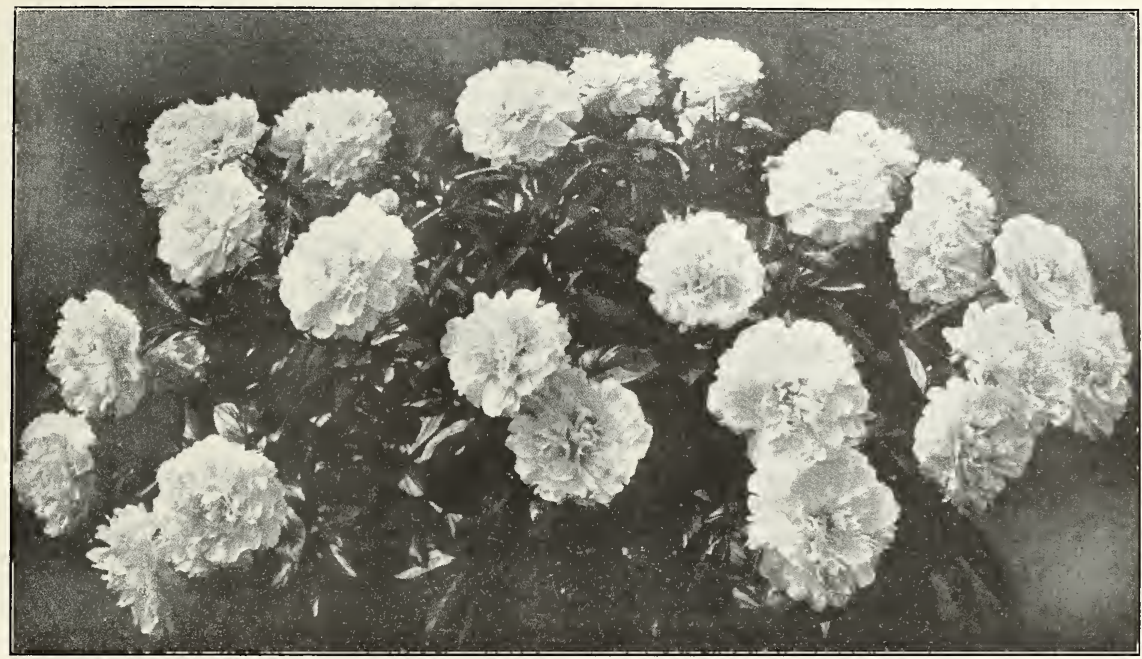

\section{The History of the Peony}

The Peony, like the Rose, can be traced back to ancient times, but the species PAEONIA ALBIFLORA (so popular to-day), or, as it is commonly known, the Chinese Peony, is of modern development.

The species OFFICINALIS is indegenous to Europe, and it is probably this class which is referred to in the writings of the ancient Greeks, and concerning which there were so many peculiar and superstitious legends.

So $f a r$ as can be learned, the Albiflora type, with which we are most concerned, did not reach Europe or America until early in the nineteenth century. It appears that at first there was little general and determined effort made to improve this species, but toward the middle of this period the French hybridists (the most skillful in the world) enthusiastically took hold of this flower with results that are little short of marvelous; as is shown in the varieties we possess to-day.

Concerning the naming of this flower, Dr. Coit very interestingly relates:

"It is the species officinalis which probably secured for the genus its name. The genus Paeonia was so named by the ancients in honor of Paeon, a physician, who cured the wounds received by the heathen gods during the Trojan war. The ancient writers, who transformed simple facts into fabulous histories for the purrose of deifying favorite mortals. relate that Paeon, who was a pupil of the great Aesculapius, first received the peony on Mt. Olympus from the hands of the mother of Apollo, with which he cured Pluto of a wound he had received from Hercules, but this cure caused so much jealousy in the breast of Aesculapius that he secretly caused the death of Paeon. Pluto, however, retaining a greatful sense of his service, changed him into the flower which ever after bore his name."

In olden times this plant was supposed to have much medicinal value, and it appears that it was also the subject of much absurd superstitution. Dr. Coit states:

"Antiquity celebrates the virtues of this plant and places it among the wonders of the vegetable garden. Fable gives us its origin. Aesculapius its properties, and superstition ranks it among miraculous plants, assuring that demons will fly the spot where it is planted, and that even a small piece of root worn around the neck is sufficient to protect the wearer from all kinds of enchantment.

"The ancient Greeks when digging up the plant were careful to do so at night only, as it was said that if anyone attempted to meddle with it in the daytime the green woodpecker, which the gods had assigned to the plant as a protection, would dart at the eyes of the intruder."

\section{PLANTING}

The Peony is of such easy culture that there is little to be said by way of introduction as to planting. Peonies respond nobly to liberal culture. Prepare your ground well, working up deep rich soil with a good quantity of bonemeal incorporated, and you will be well repaid by the increased size of fancy blooms and the general vigor of the plants. It is best to avoid the use of animal fertilizer. The root should be set in the ground with the topmost "eyes" about three inches below the surface of the soil, and the ground well firmed around it-using care not to damage the tender buds. For permanent planting Peonies should be set from three to four feet apart each way, and left undisturbed indefinitely. When it is desired to intersperse Peonies among other hardy garden Howers, or at intervals along a border of shrubs, they should be planted in groups of from three to five, each group to be of one variety. In arranging a bed of Peonies of from fifteen to fifty roots-according to the space at command-we strongly urge the planting of one variety. For while sorts may be had that bloom in theory about the same time, the result is never satisfactory, as they come straggling into bloom one after the other and the effect desired is never wholly gained. A bed of one fine sort is a magnificent sight. 
It is a pity-for the sake of the Peony - that when the fall sets in the great majority of people forget about flowers and their gardens and turn to other things, for the fall season is the only season in which the Peony should be moved. We have discontinued spring shipments and supply roots only in the fall. To move Peonies at any other season than the months of September and October means a set-back from which the roots sometimes do not recover for two years. Most general nurserymen will supply Peonies at nearly any season of the year that they can be gotten out of the ground. But when we sell you Peonies we want them to start right in to "work" for you from the beginning, without a set-back through moving at the wrong season.

Carefully observant growers agree generally that, under normal conditions, the best time for moving Peonies is during the month of September and early October, since it is essential that some root-growth be obtained after moving and before freezing weather sets in. Buds for the following season's bloom are usually fully ripened by the last week in August; the foliage still being green at this period being no indication whatever to the contrary. We begin digging on September 1 st and no orders are filled later than November 1 st. This is for your sake-not ours.

We grow over one hundred varieties of this Queen of the garden, not varieties so nearly akin in color and form as to be duplications, and not varieties that are impossible colored freaks, masquerading in the lonesome glory of their name. All our stock is what has proved best after a process of elimination from the many hundred varieties foisted on a hopeful public, and we send it out with the assurance that the buyer gets exactly what he orders.

We do not sell divisions, a term that may mean two, three or four eyes, except to seedsmen, or on special order, preferring to send out established two, three or four-year roots, dug under our own supervision, correctly labelled and packed, and guaranteed to bloom the first season after planting if ordinary methods and care are employed.

Anyone loving or interested in peonies can make a selection by visiting our farm during the blooming season, June, when the glory of blossom can be conned for color most desired by the buyer, and an idea gained of what the Peony does in adding beauty to its surroundings. The higher pricesin our list are for varieties that are rarer but not necessarily $\mathrm{m}$ ore beautiful than those of less cost. stated.

Prices are One, One and a Half, and Two Dollars, for two, three and four-year-old, respectively, except where

$$
\begin{gathered}
2 \text { yr. } 3 \text { yr. } \\
\text { ea. ea. }
\end{gathered}
$$

Achille, Calot. 1855 Shell pink fading to lilac white. Large rose type; pleasant fragrance; tall; erect. Early ................... Adolphe Rousseau, Dessert \& Mechin, 1890. Purplish garnet; one of the darkest. Very large; semi-double; very tall. Early .....\$4.00\$5.00

Albert Crousse, Crousse, 1893. Very fresh salmon pink, delicate color. Large; compact; bomb shape; frazrant; erect; medium height. Late ............................ Alice de Julvecourt, Pele, 1857. Lilac white,
finely flecked with crimson. Medium size; compact; globular; medum height; very strong stems. Early mid-season.........

Asa Gray, Crousse, 1886. Pale lilac sprinkled with dots of deeper lilac. Large, rose shape; very fragrant; good height and habit. Mid-

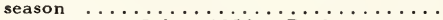

Atrosanguinea, Calot, 1850 . Dark, rosy magenta. Medium size; globular; semi-double; strong, vigorous growth. Midseason .......

Auguste Villaume, Crousse, 1895. Dark violet rose. Extra large, compact; globular; tall, strong growth. Very late ..............

Avalanche, Crousse, 1886. Creamy white, pact, crown type; fragrant; strong growth. Midseason

Arthemise. Violet rose, slightly tinted salmon. Medium size; rose type; vigorous growth.

Baroness Schroeder, Kelway. Flesh white fading to milk white. Large, globular, rose type; verv fragrant: tall, strong. Midseason

Beranger, Dessert, 1895. Clear violet rose. erect, compact growth. Very late ......

Berlioz, Crousse, 1886. Light carmine rose, tipped silver. Large, compact, globular, strong growth; medium height. Midseason

Berthe d'Hour, Calot, 1869. Tender pink with silvery shades. Medium to large, rose type; fragrant; medium height. Midseason. ......

Bo"le de Neige, Calot, 1862. Milk white, flecked with crimson. Very large. globular and compact; tall, erect growth. Early midseason. (Similar but earlier than Mons. Dupont)

Canari. Amber white collar, center clear yellow. Large; bomb shape Carnea Elegans, Guerin, 1850. Hydrangea pink. clearer center, with some carmine. Medium size; flat, rose type; fine fragrance; medium height. Midseason

Carnea Triumphans, Guerin, 1852. Pale pink with amber-white collar. Medium size;

3.00

$3.00 \quad 4.50$

Page Thirty loose, crown type; fragrant; medium height.

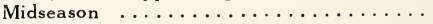

Claire Dubois, Crousse, 1886. Even, clear deep violet rose, tipped white. Very large, globular, rose type; tall, erect, strong

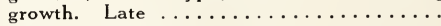

Constant Devred, Calot, 1868. Dark red carmine. Very large and full, rose type; very fragrant; medium height; strong, erect stems.

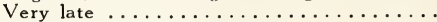

Couronne d'Or, Calot, 1873. Pure white, tipped with carmine. Large, flat, rose type medium height. Late ..............

Delachei, Delache, 1856. Violet crimson. Medium size; fairly compact, rose type strong, erect, vigorous growth. Midseason

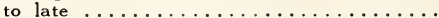

Docteur Caillot, Verdier, 1855. Brilliant Ty rian rose. Very large, rose type; fragrant strong growth. Midseason ...........

Duc de Wellington, Calot 1859. Pure white, sulphur center. Large, bomb shape; very fragrant; tall, erect growth. Midseason. (Very similar to Duchess de NemoursCalot.) . . . . . . . . . . . . . .

Duchesse de Nemours, Calot, 1856. Pure white Medium size; cup-shape bloom; fragrant medium height; vigorous. Early ........

Delicatissima. Very pale lilac rose. Large, rose type; very strong, vigorous growth; medium

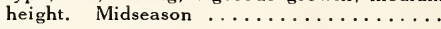

Dorchester, Richardson, 1870. Pale pink. Large, compact, rose type; fragrant; medium height; strong, thick stems. Late midseason

Edouard Andre, Mechin, 1874. Dark carmine violet. Medium size; semi-double; low- compact-growing plant. Mid-season ..........

Edulis Superba, Lemon, 1824. Dark, pink, even color. Large, loose, flat when fully open; fragrant; strong, upright growth.

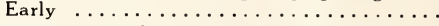

Eugene Bigot, Dessert, 1894. Brilliant red. Medium size, compact, globular, semi-rose type; fair, upright growth. Midseason... 5.00

Eugene Verdier, Calot, 1864 . Very light pink with lilac-white collar. Large, rose type: extra strong-growing plant; erect, rather

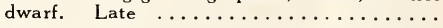

Eugenie Verdier, Calot, 1864. (Also called Pottsi alba.) Pale pink, center deeper, flecked crimson. Large, flat rose type; rather loose; fragrant; tall; free. Midseason....
$2 \mathrm{yr} .3 \mathrm{yr}$ ea. ea. 
2 yr. 3 yr.

Felix Crousse, Crousse, 1881. Very brilliant red. Medium to large, globular, typical bomb shape; fragrant; strong growth. Midseason

Festiva, Donkalaer, 1838. Pure paper white with crimson markings in center. Large, full; very fragrant; dwarf. Late. (Bloom similar to Festiva Maxima). ...........

Festiva Maxima, Miellez, 1851. Paper white with crimson markings in center. Very large and full, rose type; very tall, strong growth.

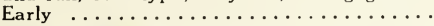

Francois Ortegat, Parmentier, 1850. Dark amaranth red. Large rose type; loose; med-

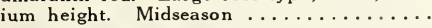

Francois Rousseau, Dessert, 1909. Very brilliant red. Large, globular, good shape. Very early ................. 5.00

Fuji-mine, Japan. Pure white collar, yellowishwhite center. Japanese type; tall, upright,

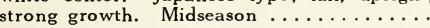

General Bertrand, Gierin, 1845. Dark pink, sil very center. Large, compact, globular, with broad collar; fragrant; tall, strong, upright growth. Early ..... $\ldots \ldots \ldots \ldots$.

General Cavaignac, Calot, 1856 . Light violet rose, edged lighter, center splashed with crimson. Very large, globular, compact; tall,

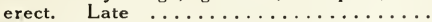

Germaine Bigot, Dessert, 1902 . Pale lilac rose, center flecked crimson. Very large, flat, crown shape; strong and erect growth.

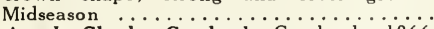

Gloire de Charles Gombault, Gombault, 1866. Light rose collar and crown, cream center. Medium size; deep globular crown; tall, strong. Midseason . . . . . . . . .

Grandiflora Rosea, Guerin, 1850 . ferino red collar, center lighter, shaded salmon. Large, globular, rose type; fragrant; tall; strong. Midseason ...............

Grandiflora, Richardson, 1883 . Uniform rose white. Very large, flat, rose type; very fragrant; tall, erect. Very late ..........

Henry Demay, Calot, 1866. Aniline red, with silver reflex. Medium size; globular, bomb type; fragrant; strong, vigorous. Midseason

Humei, 1810. Cherry pink. Medium size, compact, globular, rose type; medium height.

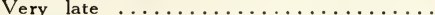

James Kelway, Kelway. (Synonym, Lady Derby.) Rosy white, changing to milk white. Very large, loose, rose type; fragrant; tall, strong grower. Early midseason ........

Jeanne d'Arc, Calot, 1858. Pale lilac rose, cream-white center, pink crown. Medium to large, crown shape; fragrant; strong. Early (Similar to Golden Harvest.) ...........

Jules Calot, Calot, 1861 . Dark pink, with silvery reflex. Large, flat, rose type; fragrant; strong; medium height. Midseason......

Lady Isadore, Donin \& Hoppner, 1893. Pure white, petals edged red, very large and deep; tall; fine bloomer. Midseason......... $6.00 \quad 9.00$

La Lorraine, Lemoin, 1901 . Cream white. Very large, globular, bomb type; fragrant; medium height. Midseason ............15.00 20.00

Lamartine, Calot, 1860 . (Also called Gigantea.) Pale lilac rose, darker center. Very large, loose, irregular, rose shape; very fra-

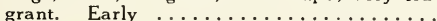

La Tendresse, Crousse, $i 896 . \cdots$ Milk white, slightly splashed with crimson. Very large, compact, flat, rose type; fragrant; strong

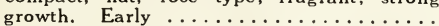

La Tulipe, Calot 1872 . Lilac $^{\text {growthite, outer }}$ petals striped crimson. Large, flat, rose type; fragrant; very tall, strong growth. Late midseason

Livingstone, Crousse, 1879 Pale lilac rose, silver tipped, some carmine spots. Large, compact, rose type; tall; very strong stems. Late

Lurano, Pleas. Light pink. Large, loose, semi-double; pleasing fragrance; medium

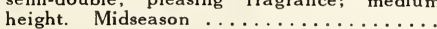

Mme. Barillet Deschamps, Calot, 1868. Clear violet rose, fading to a delicate silver pink. Large, flat, imbricated, rose type; fragrant; medium height. Midseason ............

Mme. Boulanger, Crousse, 1886. Glossy soft pink, shaded lilac, silvery-flesh border. Large, very compact, rose type; upright, medium height. Late midseason ........

Mme. Bucquet, Dessert, 1888. Uniform, very dark amaranth. Large, loose, rose type; fragrant; strong, upright growth. Midseason

Mme. Calot, Miellez, 1856. Very pale pink center, shaded darker, silver tint. Very large, rose type; very fragrant; tall, strong, upright. Early ................

Mme. Camille Bancel, Crousse, 1897. Uniform deep pink, with silver shades. Large, globular, perfect rose type; fragrant; medium height. Late ..................

Mme. Chaumy, Calot, 1864. Pale lilac rose, center slightly darker. Medium size; very compact, rose type; very free; medium height. Midseason .................

Mme. Crousse, Calot, 1866. Pure white, with faint crimson markings. Large, globular, crown type; fragrant; medium height. Mid-

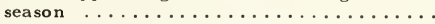

Mme, de Galhau, Crousse, 1883. Pale lilac rose, with a rose-white collar. Very large, compact, rose shape; very fragrant; strong

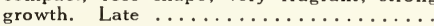

Mme. de Verneville, Crousse, 1885. Pure white, center tipped with carmine. Very large, full, bomb shape; fragrant; medium height; strong growth. Early ...........

Mme. d'Hour, Calot, 1864. Light pink, silver tipped, center shaded darker. Large compact, rose type; medium height and growth.

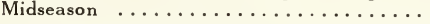

Mme. Ducel, Mechin, 1880. Light rose, silver reflex. Large, perfect globe, bomb shape; fragrant; medium height; very strong growth

Mme. Emile Galle, Crousse, 1881 . pink, changing to milk white in center. Very large, compact, flat, rose type; tall,

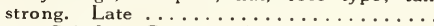

Mme. Geissler, Crousse, $1880 . \cdots$ Violet $\ldots \ldots$ tipped silver. Very large, very compact, globular rose type; pleasing fragrance; medium height and growth. Late midseason.

Mme. Jules Calot, Calot, 1869. Lilac white some carmine flecks in center. Very dwarf, large, compact, rose type; strong, vigorous growth. Midseason $\ldots \ldots \ldots \ldots \ldots \ldots \ldots \ldots$

Mme. Lebon, Calot, 1855. Showy cherry pink to aniline red. Medium to large, very compact, rose type; pleasing fragrance; strong growth. Late

Mme. Lemoinier, Calot, 1865 Pale lilac fading to lilac white, collar splashed with crimson. Large, compact, rose type; fragrant; tall, vigorous. Midseason to late....

Mme. Reignous, Dessert, 1909. Dark pink, silver border. Large, full. Verv early ...
Mlle. Renee Dessert, Mechin, 1880 . Uniform Mlle. Renee Dessert, Mechin, 1880. Uniform pure mauve, silver tipped. Large, globular.

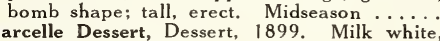
Marcelle Dessert, Dessert, 1899. Milk white,
splashed with lilac and crimson. Large, crown shape; very fragrant; medium height.

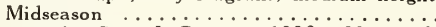

Marguerite Gerard, Crousse, 1892 Very pale salmon pink, fading to almost white. Large, compact, rose type; medium height; very

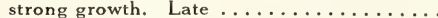

Marie d'Hour, Calot, 1883 . Pale pink, darker center, flecked carmine. Large, globular, rose type; erect; rather dwarf. Midseason

Marie Lemoine, Calot, 1869. Pure white, with cream-white center. Large, very compact, rose type; pleasing fragrance; medium height extra strong stems. Very late .........
.00 6.00

$3.00 \quad 4.00$ 
Mathilde de Roseneck, Crousse, 1883. Uniform pale lilac rose, center deep carmine. Very large, globular, rose type; very fragrant; very tall, strong growth. Late ........

Modele de Perfection, Crousse, 1875 . ' Light pink, silver tipped, darker center. Very large, compact, rose type; fragrant; vigorous

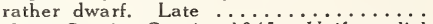

Modeste Guerin, Guerin, 1845 . Uniform light solferino red. Large, compact, bomb shape; fragrant; medium height; extra strong stems.

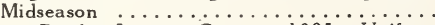

Mons. Bastien Lepage, Crousse, 1885 . Uniform pure mauve, silvery reflex. Very large, crown shape; incurved petals; tall, extra

Mons. Dupont, Calot, 1872 . Milk white, cen-

Mons. Jules Elie, Crousse, 1888. Pale lilac rose,

Mons. Krelage, Crousse, 1883. Solferino red, medium height; strong growth. Late ....

Mons. Marír Cich zak, Dessert. 1899. Verv

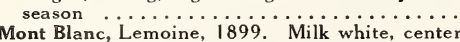
very strong, thick stems. Early midseason

Philomele, Calot, 1861. Yellow, fading to strong growth. Midseason ….....

Pierre Dessert, Dessert \& Mechin, 1890

Pierre Duchartre, Crousse, 1895. Tender flesh

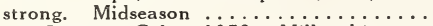
ter splashed with crimson. Large, rose type; fragrant: tall, erect. Late midseason . ". . silvery reflex. Very large, compact, globular; very fragrant; tall, vigorous growth. Early silver tips. Large, compact, semi-rose type dark purple garnet, with black reflex. Meddium to large, globular, rose type; medium height; strong, vigorous growth. Early midslightly tinted rose. Extra large, very compact, globular, rose type; fragrant; erect; cream, with bright pink collar and crown. Medium size; low, flat crown; medium height pact, rose type; tall, strong stems. Early

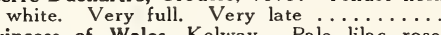

$2.00 \quad 3.00$

4.50

$5.00 \quad 7.50$

$7.50 \quad 10.00$ guards flecked crimson, clear center. Large size: flat, compact, crown type; fragrant; medium height. Late .............
Prolifera Tricolor, Lemon, 1825. White, tinted pink, sulphur-yellow center. Medium size; very loose, anemone type; fragrant; medium

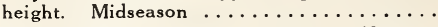

Purpurea Superba, Delache, 1855. Uniform dark purple. Large, compact, globular, crown shape; erect; very tall, vigorous

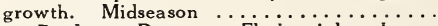

Rosa Bonheur, Dessert. Flesh pink. Large, rose shape; dwarf ..............

Rubra Triumphans, Guerin, 1840 . Very dark crimson. Large, loose, semi-double; medium height; strong growth. Early ...........

Simone Chevalier, Dessert, 1902. Pale lilac rose, cream-white collar. Large medium compact, crown type; very fragrant; medium

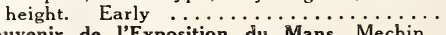

Souvenir de l'Exposition du Mans, Mechin, 1880. Reddish violet, with silvery reflex. strong vigorous. Midseason ............ strong vigorous. Midseason ............

Souvenir de l'Exposition Universelle, Calot, Very large, flat, rose tyne, fragrant; medium height; free. Late midseason .......... Stanley, Kelway. Dark crimson. Large, single; medium height; erect. Early mid-

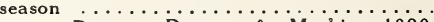

Suzanne Dessert, Dessert \& Mechin, 1890 . Clear rose pink; does not fade. Large, compact, bomb type; fragrant; erect, medium

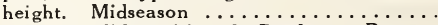

Souvenir de l'Exposition de Bordeaux, Dessert 1896. Bluish violet with wine color reflex.

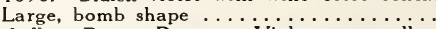

Umbellata Rosea, Dessert. Violet- rose collar. with amber-white center. Medium to large, informal rose type; medium height; very

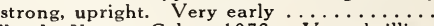

Ville de Nancy, Calot, 1872 . Very brilliant red. Large bomb shape; tall, very strong

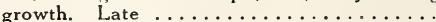

Virgo Maria, Calot, 1859 . Pure ivory white, without markings. Large bomb type; fragrant: medium height. Late .............

Venus, Kelway. Very delicate pale pink, lighter collar. Very large, high, compact crown very fragrant; tall, erect. Midseason .....

\section{HARDY PHLOX}

For hardy clumps of brilliantly colored masses of flowers on the lawn among the shrubbery, Hardy Perennial Phlox takes the first rank. The great, showy heads of bloom are produced in gorgeous profusion from midsummer until checked by frost. Their range of color is from the deenest of reds, scarlets and purples to the finest of pinks, lavenders and pure whites. We offer the following varieties-Field-grown at 25c each, \$2.50 per dozen:

Albion, (Medium). Producing very large panicles of pure white flowers, with faint aniline-red eye.

Bacchante, (Medium). Tyrian rose with crimson-carmine eye.

Bridesmaid, (Tall). White, with large crimson-carmine centre.

Champs Elysee, (Dwarf). A very bright rosy magenta

Crepuscle, (Medium). Shading from a deep crimson centre, through rose-lilac to a white edge.

Europa, (Medium). A white variety with very decided crimson-carmine eye. The individual flowers as well as the trusses are very large.

Eclaireur, (Tall). Brilliant rosy magenta, with larg? light halo.

Jeanne D' Arc, (Tall). A good standard, late white. La Vague, (Medium). Pure mauve, with aniline-red eye. L'Esperance, light lavender rink, with large, white eye flowers large. One of the finest and most distinct varieties in our collection.
Lothair, salmon red with carmine eye.

Mauve Queen, (Medium). Pleasing bright mauve.

Pink Beauty, pale pink, enormous spike.

Rheinlander, (Medium). A most pleasing salmon-pink with flowers of immense size.

Rhynstrom, (Medium). Bright carmine-rose. Very striking en masse.

Thor, (Medium). A beautiful lively shade of deen salnon pink suffused and overlaid with a deep scarlet glow large white halo and aniline-red eye.

Von Lassburg, (Medium). The purest white in cultivation, individual flowers larger than any other white.

W. C. Egan, (Medium). One of the finest Phloxes ye introduced, the color effect as a whole is a delicate, pleas ing shade of soft pink.

Early Flowering Hardy Phlox, (Phlox Suffruticosa)

Miss Lingard, this grand free-flowering white variety is universal favorite. Coming into flower in May, it continues in flower throughout the season. Price 25c, $\$ 2.50$ per doz. 
Do not be discouraged if your dahlias do less than you expect the first season. Many of the finer varieties need acclimating, and sometimes fail to respond to changed conditions the first year, but their second year showing will surprise you. Many times a second trial proves my first year judgment wrong.

\section{sive 'Life was mine. \\ And I who pass with ut regret or grief, Have cared the more to make my moment fine. Because it was so brief. \\ FLORENCE EARLE COATS.}

It seems but yesterday that our gardens glowed with the passing summer's glory, and now 'the melancholy days are come,' and 'Heaped in the hollows of the grove, the autumn leaves lie dead', the occasional sunny day, harbinger of tomorrow's hastening spring, joys us with garden promises, and our happle $t$ hours are spent in the gleam of the blazing logs, dreaming of and planning next summer's garden days.

Who that loves a garden has not shared with us the pleasure of creating diream gardens, ' beds of beauty and winding paths, rose nooks and rock bowers, rustic bridge and lily pond, perfumed arbor and velvet lawn? What though Old Winter

$$
\begin{aligned}
& \text { And hail and nim dors blan, } \\
& \text { Or the stormy north sen't riving forth } \\
& \text { The blinding sleet and snaw, }
\end{aligned}
$$

our dream gardening goes merrily on. We can build, blot out, and build anew, and in the ideal achieved we live awhile, insentient to worry, submarines or sealing-wax, peace conference or kings-

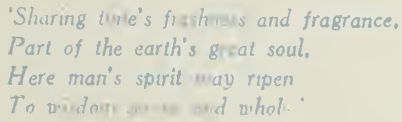

Abraham Cowley said, 'Cod the firel ganden made, and the first city Cain', and I like to think that because Cain's work has been done =o well, God scatters fragments of His garden broadcast over the cities Cain's sons erect, and grants to each the hope of making the dream garden true ; and to every garden lover, in town or country, I grant a share in rny garden dreams, and hope some day, we'll boild as we have dreamed.

How fast the hours in my garden pass? The midnight hour is striking, and

$$
\begin{aligned}
& \text { "Spoet deef I with s, ine and all! } \\
& \text { And if upon its silliness fall } \\
& \text { The visions of a busy brain. } \\
& \text { We'll have us plea we o'er agaw, } \\
& \text { To warm the heart, to charm the sight, } \\
& \text { Gay dreams to all, good night, good night." }
\end{aligned}
$$


